\title{
FAKTOR-FAKTOR YANG MEMPENGARUHI AKUISISI PENGETAHUAN DALAM PEMBELAJARAN DARING DI MASA PANDEMI COVID-19
}

\author{
Samuel Andrean Yahya ${ }^{1,2}$, Maria Widyarini ${ }^{2}$, Oki Sunardi ${ }^{3}$ \\ ${ }^{1}$ Code for Social, Bandung \\ ${ }^{2}$ Magister Administrasi Bisnis, Universitas Katolik Parahyangan, Bandung \\ ${ }^{3}$ Fakultas Teknologi Industri, Universitas Kristen Krida Wacana, Jakarta \\ yahya.samuel@gmail.com \\ widya@unpar.ac.id \\ oki.sunardi@ukrida.ac.id
}

\begin{abstract}
ABSTRAK
Pandemi COVID-19 yang melanda dunia memaksa sekolah dan universitas untuk mengganti metode pembelajaran yang sebelumnya dilakukan secara tatap muka menjadi pembelajaran daring. Pembelajaran daring memberikan tantangan dimana para peserta didik mengalami kesulitan untuk memahami dan mengakusisi materi pembelajaran dari pendidik. Penelitian ini dilakukan untuk mengeksplorasi faktor-faktor yang dapat berpengaruh terhadap akuisisi pengetahuan selama perkuliahan daring dan mengetahui efektivitas pembelajaran daring. Berdasarkan tinjauan pustaka, dirumuskan sebuah model penelitian dengan tiga faktor yang kemungkinan berpengaruh signifikan terhadap akusisi pengetahuan selama pembelajaran daring, yaitu faktor infrastruktur teknologi informasi, faktor individu, dan faktor universitas sebagai variabel independen, efektivitas pembelajaran daring sebagai variabel dependen, dan akuisisi pengetahuan sebagai variabel mediator. Penelitian ini menggunakan metode kuantitatif, dimana kuesioner disebarkan kepada mahasiswa aktif program studi Ilmu Administrasi Bisnis, Universitas Katolik Parahyangan Bandung. Sebanyak 295 mahasiwa memberikan jawaban terhadap kuesioner yang telah dibagikan. Uji validitas, reliabilitas, dan uji hubungan antar variabel diukur menggunakan software SPSS. Hasil penelitian menunjukkan bahwa variabel faktor individu dan faktor universitas berpengaruh signifikan positif terhadap akuisisi pengetahuan, sedangkan infrastruktur teknologi informasi berpengaruh signifikan negatif terhadap akuisisi pengetahuan. Selain itu, akuisisi pengetahuan berpengaruh signifikan positif terhadap efektivitas pembelajaran daring, akusisi pengetahuan memediasi hubungan antara faktor individu dan efektivitas pembelajaran daring. Hasil penelitian juga menunjukkan perkuliahan daring di program studi Ilmu Administrasi Bisnis sudah berjalan dengan efektif.
\end{abstract}

Kata kunci: daring, pembelajaran, efektivitas, akuisisi, pengetahuan

\begin{abstract}
The COVID-19 pandemic enforced schools and universities to shift from traditional face to face learning into online learning. Sudden educational shift brought difficulties for students who were struggling to understand and acquire knowledge from teachers during online learning. The purpose of this study is to explore factors influencing students' knowledge acquisition during online learning and measuring online learning effectiveness. Based on the literature review, a model has been proposed with three factors that are expected to have significant impact on students' knowledge acquisition during online learning. Technology infrastructure, individual factor, university factor are independent factors, while online learning effectiveness is dependent factor and knowledge acquisition acts as mediating variable. The primary data were collected through questionnaire given to active students from Department of Business Administration, Parahyangan Catholic University. 295 students submitted their response for the research. Validity analysis, reliability analysis, and hypotheses test were conducted using SPSS. The finding reveals that individual factor and university factor have significant positive impact on knowledge acquisition, while information technology has significant negative impact on knowledge acquisition. The results also showed that knowledge acquisition have significant positive impact on online learning effectiveness, and acts as mediating variable between individual factor and online learning effectiveness. Moreover, the results also revealed that online learning in Department of Business Administration has run effectively.
\end{abstract}

Keywords: online, learning, effectiveness, knowledge, acquisition

\section{PENDAHULUAN}

Pandemi COVID-19 menyebar dengan cepat ke seluruh dunia dan berdampak pada pembatasan dan larangan mengadakan kegiatan yang melibatkan banyak orang, salah satunya kegiatan belajar mengajar di institusi pendidikan untuk mencegah penularan virus secara masif. Untuk mengantisipasi penyebaran virus COVID19, pemerintah Indonesia mengeluarkan kebijakan untuk beraktivitas dan belajar dari rumah (Ihsanuddin, 2020). Melalui Surat Edaran 
Mendikbud No 4 tahun 2020 tentang Pelaksanaan Kebijakan Pendidikan Dalam Masa Darurat Penyebaran Coronavirus Disease (Covid-19), sektor pendidikan formal dari jenjang sekolah dasar sampai perguruan tinggi diharuskan mengganti metode pembelajaran yang biasa dilakukan tatap muka menjadi metode pembelajaran jarak jauh secara daring (Mendikbud, 2020). Kegiatan belajar mengajar yang sebelumnya dilakukan tatap muka, harus digantikan dengan kegiatan belajar mengajar yang terpisah jarak, dimana komunikasi antar pelajar dan pengajar dilakukan melalui media daring seperti Zoom, Google Classroom, e-learning. Data menunjukkan sebanyak 68 juta pelajar sekolah dan 4670 mahasiswa perguruan tinggi tidak dapat mengikuti kegiatan belajar mengajar tatap muka dan sekitar 4 juta guru dan/atau dosen mengajar menggunakan metode pembelajaran daring (Jakarta Globe, 2020; Kemendikbud, 2020). Di satu sisi, pembelajaran jarak jauh secara daring memberikan kemudahan berupa fleksibilitas belajar, kemudahan mengatur waktu, penghematan biaya, dan jangkauan akses yang lebih luas. Di sisi lain, pembelajaran jarak jauh menimbulkan tantangan baru bagi institusi pendidikan di Indonesia yang sebelumnya terbiasa melakukan pembelajaran tatap muka (offline). Pada praktiknya, masih banyak permasalahan yang dihadapi baik tenaga pendidik, pelajar, maupun mahasiswa dalam menerapkan perkuliahan daring jarak jauh tersebut.

Hasil evaluasi pembelajaran daring selama pandemi COVID-19 yang dilakukan Direktorat Jenderal Pendidikan Tinggi Kementerian Pendidikan dan Kebudayaan Indonesia menemukan sejumlah permasalahan yang dialami pendidik dan peserta didik di tingkat perguruan tinggi (Hutasoit, 2020; Kasih, 2020). Beberapa permasalahan tersebut antara lain peserta didik mengalami kesulitan mengikuti pembelajaran daring dikarenakan kesulitan berkomunikasi, kesulitan fokus dan memahami konsep pelajaran yang bersifat eksak, ditambah banyaknya beban tugas yang diberikan (Hutasoit, 2020; Russanah, 2020). Permasalahan lain yang ditemukan adalah keterbatasan kuota internet dan belum meratanya infrastruktur internet sehingga menghambat pembelajaran daring dan mengganggu efektivitas pembelajaran daring.

Pandemi COVID-19 yang belum mereda di tahun 2020, menyebabkan pembelajaran daring jarak jauh untuk perguruan tinggi diperpanjang sampai batas waktu yang belum ditentukan (Kasih, 2020). Pembelajaran jarak jauh secara daring yang belum dijalankan secara efektif dapat berdampak buruk pada aspek kognitif dan psikis peserta didik dan juga berdampak pada kesenjangan pendidikan seperti penurunan kualitas lulusan yang ada. Hal ini menunjukkan bahwa perguruan tinggi memiliki peran penting terhadap keberhasilan dan efektivitas pembelajaran yang berpengaruh terhadap perkembangan intelektual serta kemajuan sumber daya manusia dan perekonomian di suatu negara (Arsana, 2020; Fauzi, Nya-Ling, Thursamy, \& Ojo, 2019). Oleh karena itu, perkuliahan daring di tingkat perguruan tinggi yang dijalankan semasa pandemi perlu diperbaiki supaya pembelajaran daring jarak jauh dapat lebih efektif.

Permasalahan yang dihadapi institusi pendidikan Indonesia selama pandemi COVID-19 ini salah satunya disebabkan karena ketidaksiapan institusi pendidikan di Indonesia menerapkan metode pembelajaran daring (Nugroho, 2020; Ridhoi, 2020). Perubahan metode pembelajaran dari luring menjadi daring tanpa persiapan sebelumnya mengakibatkan berbagai institusi pendidikan mengalami kesulitan beradaptasi menggunakan metode pembelajaran daring (Ridhoi, 2020). Hasil survei terhadap pembelajaran daring di tingkat universitas menunjukkan 52\% dari total universitas negeri dan $40 \%$ dari total universitas swasta di Indonesia belum pernah menerapkan pembelajaran daring sebelum masa pandemi (Dzulkifar, 2020). Fenomena tersebut disebabkan karena sistem pembelajaran daring di perguruan tinggi Indonesia belum bersifat wajib sehingga belum diterapkan secara merata serta kurangnya kapasitas, insentif, dan kapabilitas pengajar memanfaatkan media daring, yang membuat pembelajaran daring tidak diterapkan sama sekali (Azzahra, 2020). Penyebab lainnya adalah ketidakleluasaan dalam membagikan pengetahuan yang membutuhkan close interaction, keterbatasan alat peraga pendukung, kesulitan berdiskusi dan belajar bersama, mudah terjadi 
miskomunikasi dan kesulitan memantau kemajuan peserta didik selama proses perkuliahan daring (Alawamleh, Al-Twait, \& Al-Saht, 2020; Ilyas \& Zaman, 2020). Keberhasilan pembelajaran daring memerlukan keterlibatan berbagai aktor kunci di sektor pendidikan, misalnya pemerintah sebagai pembuat kebijakan, pengawas, pemberi bantuan dan penyedia layanan akses internet dan kuota yang bisa diakses semua mahasiswa (Peterson, Scharber, Thuesen, \& Baskin, 2020). Perguruan tinggi sendiri juga perlu menerapkan strategi efektif untuk meningkatkan efektivitas perkuliahan daring.

Institusi pendidikan seperti perguruan tinggi merupakan institusi yang berbasis pengetahuan, karena di dalamnya terdapat aktivitas mengakuisisi, menghasilkan, membagikan pengetahuan dalam lingkup organisasi. Pengetahuan mempunyai peran krusial dalam kemajuan institusi pendidikan, mengingat pengetahuan merupakan aset berharga yang dapat meningkatkan kemajuan institusi pendidikan (Thanki \& Thakar, 2018). Selain itu, institusi pendidikan berkontribusi pada kemajuan pembangunan sumber daya manusia dan ekonomi suatu negara, yang menyebabkan peran pengetahuan dalam institusi pendidikan menjadi krusial (Fauzi et al., 2019). Kegiatan belajar mengajar di institusi pendidikan melibatkan proses knowledge transfer antara pengajar dan pelajar, dimana terdapat proses akuisisi pengetahuan yang dilakukan peserta didik (Iqbal, Latif, Marimon, Sahibzada, \& Hussain, 2019; Jain \& Gupta, 2019). Hal ini menunjukkan bahwa efektivitas proses belajar mengajar dapat dilihat menggunakan pendekatan knowledge management (Veer Ramjeawon \& Rowley, 2017).

Penelitian-penelitian terdahulu telah meneliti faktor-faktor yang berpengaruh terhadap keberhasilan akuisisi pengetahuan sebagai bagian dari proses pengelolaan pengetahuan dalam lingkup organisasi. Penelitian yang berkaitan dengan pengelolaan pengetahuan di sektor pendidikan masih terbatas diteliti dibandingkan sektor lain seperti manufaktur (Al Kurdi et al, 2018; Boatel et al, 2014). Topik penelitian yang meneliti pengelolaan pengetahuan di sektor pendidikan lebih difokuskan pada pembelajaran konvensional dan dibatasi dalam lingkup anggota organisasi, misalnya antar sesama staf akademik, atau antar departemen di institusi pendidikan; belum banyak penelitian yang meneliti faktor yang berpengaruh terhadap pengelolaan pengetahuan antar jawatan yang berbeda, misalnya antara pendidik dan peserta didik (Ramjeawon \& Rowley, 2017; Al Kurdi et al, 2018; Krishnashwamy et al, 2019). Sektor pendidikan menjadi sektor yang turut terpengaruh dampak pandemi COVID-19 secara signifikan, dimana perguruan tinggi menghadapi tantangan dalam menjalankan proses pembelajaran daring yang efektif dan membuat peserta didik mampu menguasai materi pembelajaran yang dibagikan secara daring. (Zhu et al, 2020; Alawamleh et al, 2020). Oleh karena itu, penelitian ini dilakukan untuk mengetahui faktor-faktor yang dapat meningkatkan akuisisi pengetahuan selama proses pembelajaran daring sehingga proses pembelajaran daring dapat berjalan efektif. Penelitian ini dilakukan menggunakan studi kasus Universitas Katolik Parahyangan (UNPAR) Bandung, dan dibatasi pada program studi Ilmu Administrasi Bisnis (PSIAB) untuk memudahkan perolehan data penelitian.

Rumusan masalah dalam penelitian ini, adalah :

1. Bagaimana efektivitas pembelajaran daring jarak jauh yang dilakukan selama pandemi COVID-19 di UNPAR, khususnya di PSIAB?

2. Faktor apakah yang dapat berpengaruh terhadap keberhasilan akuisisi pengetahuan saat proses pembelajaran daring untuk meningkatkan efektivitas pembelajaran daring di PSIAB UNPAR Bandung?

\section{KAJIAN LITERATUR}

Untuk menemukan literatur relevan yang membahas faktor-faktor berpengaruh terhadap akuisisi pengetahuan, dilakukan pembatasan berdasarkan database artikel jurnal lima tahun terakhir dari Emerald Insight dengan menggunakan sejumlah kata kunci pada database jurnal. Kata kunci yang digunakan berdasarkan topik penelitian. Kemudian, dilakukan pengkajian abstrak dan pengkajian ulang keseluruhan jurnal yang telah disortir sebelumnya untuk mengetahui 
jurnal yang relevan sebagai dasar untuk merumuskan hipotesis penelitian.

\section{Pembelajaran Daring}

Perkembangan teknologi dan digitalisasi mendisrupsi pembelajaran konvensional di sektor pendidikan pada berbagai tingkat dan mengakibatkan maraknya pembelajaran daring. Sektor pendidikan termasuk perguruan tinggi beradaptasi sesuai perkembangan teknologi untuk mendesain pembelajaran sedemikian rupa untuk menciptakan lingkungan pembelajaran yang terbuka, relevan, tidak membosankan, dan fleksibel untuk diterapkan pengajar dan pelajar (Xiao, SunLin, \& Cheng, 2019).

Pembelajaran konvensional merupakan sistem pembelajaran yang melibatkan interaksi dan komunikasi verbal secara langsung antar pengajar dan pelajar, tanpa dipisahkan oleh jarak dan waktu, sedangkan pembelajaran daring merupakan sistem pembelajaran yang tidak melibatkan interaksi fisik dan proses tatap muka secara langsung (remote learning) antara guru dan murid serta antar murid karena terpisah oleh jarak (Ilyas \& Zaman, 2020; Meskhi, Ponomareva, \& Ugnich, 2019; Xiao et al., 2019). Pembelajaran daring memanfaatkan teknologi informasi dan komunikasi seperti media sosial, aplikasi digital, platform daring untuk menunjang proses pembelajaran dan interaksi yang terpisahkan oleh jarak sekaligus menciptakan smart classroom yang mudah diakses semua pihak (Xiao et al., 2019).

Kelebihan pembelajaran daring antara lain meningkatkan fleksibilitas dalam mengatur pembelajaran, meningkatkan aksesibilitas bagi semua lapisan masyarakat, menghemat waktu dan biaya belajar, meningkatkan transparansi dalam proses pembelajaran, memudahkan evaluasi proses pembelajaran (Meskhi et al., 2019; Pretorius, Lombard, \& Khotoo, 2016). Pembelajaran daring memberikan kesempatan pada individu yang tidak dapat mengikuti pembelajaran konvensional karena keterbatasan waktu dan tempat. (Montgomerie, Edwards, \& Thorn, 2016). Pembelajaran daring memberikan keleluasaan pengguna mengatur waktu dan tempat belajar, tetapi memerlukan komitmen dan tanggung jawab dari pelajar untuk dapat mengalokasikan waktu secara efektif dan memantau kemajuan belajar daring secara mandiri (Alawamleh et al., 2020; Carter, Rice, Yang, \& Jackson, 2020). Dari sudut pandang pengajar, pembelajaran daring membutuhkan perencanaan yang lebih matang dibandingkan pembelajaran konvensional karena pengajar tidak dapat leluasa memanfaatkan bahasa tubuh dan ekspresi wajah untuk mempermudah pemahaman dan penguasaan materi layaknya pembelajaran konvensional tatap muka dan membutuhkan interaksi dan komunikasi yang efektif supaya dapat memotivasi dan mendorong para peserta didik dapat mengikuti proses pembelajaran secara efektif (Carter et al., 2020). Lingkungan dan atmosfir pembelajaran daring perlu dibuat sedemikian rupa agar dapat mendorong para individu berpartisipasi secara aktif dalam aktivitas belajar mengajar daring sehingga proses belajar dapat meningkatkan perkembangan kognitif peserta didik (Alawamleh et al., 2020).

Pembelajaran dikatakan efektif bila tujuan proses belajar mengajar yang di dalamnya terdapat pertukaran ide, informasi, pemikiran, pengetahuan dapat tercapai, dapat dilihat dari hasil evaluasi pembelajaran peserta didik dan pendidik (Alawamleh et al., 2020). Pembelajaran yang efektif memerlukan kurikulum yang dapat menguji kemampuan kognitif, mengolah data, berpikir logis dan kritis, sekaligus memerlukan interaksi dan partisipasi aktif antara tenaga pendidik dan peserta didik (Carter et al., 2020). Xiao et al (2019) menyatakan bahwa proses pembelajaran perlu mengkombinasikan pembelajaran daring dan offline untuk meningkatkan efektivitas pembelajaran. Pembelajaran yang efektif memerlukan suasana pembelajaran yang interaktif sekaligus dapat memenuhi target pencapaian yang dapat dilihat dari proses evaluasi dan perolehan nilai akademik (Jain \& Gupta, 2019). Penelitian terdahulu menunjukkan pembelajaran daring yang efektif perlu menciptakan suasana lingkungan belajar virtual yang interaktif yang ditunjang oleh pemanfaatan teknologi, seperti e-learning yang merupakan sistem berbasis web yang memungkinkan informasi dan pengetahuan yang dapat diakses pengguna tanpa batasan ruang dan wilayah (Charband \& Jafari Navimipour, 2018; Meskhi et al., 2019). Pembelajaran daring yang 
efektif didukung oleh sejumlah faktor lain, seperti motivasi dan kesadaran individu untuk mengikuti pembelajaran daring, karakter personal, dukungan sesama kolega, budaya organisasi yang mendukung pembelajaran daring (Iqbal et al., 2019; Watjatrakul, 2020). Pembelajaran daring yang efektif juga didukung oleh computer efficacy atau kemampuan pendidik dan peserta didik memanfaatkan aplikasi di komputer untuk menunjang pembelajaran daring, keyakinan individu terhadap pentingnya pembelajaran daring, lingkungan sosial yang interaktif dan saling mendukung (Montgomerie et al., 2016). Di tingkat perguruan tinggi, pembelajaran yang efektif dapat meningkatkan output berupa produktivitas akademik, yang dapat dilihat dari peningkatan nilai kognitif peserta didik dan peningkatan jumlah publikasi, konferensi, dan penelitian yang dilakukan perguruan tinggi dan berdampak positif pada kemajuan negara (Fauzi et al., 2019)

\section{Akuisisi Pengetahuan}

Akuisisi pengetahuan dapat dilakukan baik di tingkat organisasi maupun di tingkat individu. Di tingkat organisasi, akuisisi pengetahuan merupakan proses ekstraksi dan pengelolaan pengetahuan dari berbagai sumber luar organisasi untuk meningkatkan keunggulan bersaing di tengah persaingan bisnis (Thani \& Mirkamali, 2018; Duarte Alonso, Kok, Sakellarios, \& O’Brien, 2019; Obeidat, Mai-Maher, Masa'deh, \& Tarhini, 2016). Di tingkat individu, akuisisi pengetahuan merupakan serangkaian aktivitas proses pencarian, identifikasi, pemrosesan, dan seleksi informasi, ide, pengetahuan dari sumber eksternal yang bertujuan untuk meningkatkan pengetahuan yang sudah dimiliki individu sebelumnya (Sahibzada et al, 2020). Pengetahuan yang diperoleh dari sumber eksternal dipilah-pilah dan diinternalisasikan dengan pengetahuan yang sudah ada dalam diri individu, dan dituangkan dalam bentuk memori, persepsi atau keyakinan, skill, kapabilitas.

Akuisisi pengetahuan dalam tingkat individual merujuk pada proses perubahan struktur kognitif individu dengan mengubah paradigm atau keyakinan yang tertanam dalam diri individu sebagai akibat dari memperoleh pengetahuan baru (Clark \& Creswell, 2015). Pengetahuan dapat diperoleh dari proses interaksi individu dengan lingkungan, interaksi individu dengan individu lain, pengalaman individu. Pengetahuan baru juga dapat diakuisisi dari sumber data atau informasi eksternal berupa jurnal penelitian, buku, database digital, website, diskusi, pendapat ahli (Costa \& Monteiro, 2016; Duarte Alonso et al., 2019; Holsapple, Jones, \& Leonard, 2015)

Akuisisi pengetahuan bermanfaat bagi individu yang ingin memperkaya dan mengembangkan pengetahuan dalam dirinya. Akuisisi pengetahuan memudahkan seseorang untuk meningkatkan pemahaman, memperkaya wawasan individu sehingga dapat meningkatkan kapabilitas absorbsi, kompetensi, kemampuan berpikir analitis (Supermane \& Mohd Tahir, 2018). Pengetahuan yang diperoleh dari proses akuisisi dapat dijadikan pedoman untuk mengambil keputusan dan memecahkan masalah kompleks (Bashir \& Farooq, 2019; Boateng, Dzandu, \& Tang, 2014; Gope, Elia, \& Passiante, 2018).

Akusisi pengetahuan dapat memperluas kapasitas pengetahuan individu dan memberikan kesempatan pada individu untuk memanfaatkan pengetahuan baru saat menyelesaikan tugas dan atau kewajiban yang harus dikerjakan (Rusly et al, 2015). Akuisisi pengetahuan juga berpengaruh terhadap keberhasilan individu untuk meningkatkan kapabilitas, kualitas individu, nilai kompetitif, dan kemampuan bersaing individu di dunia pendidikan maupun dunia kerja (Boateng et al., 2014; Esmaeelinezhad \& Afrazeh, 2018)

\section{Perspektif Manajemen Pengetahuan dalam Proses Pembelajaran}

Institusi pendidikan seperti perguruan tinggi merupakan organisasi berbasis pengetahuan karena dalam aktivitasnya melibatkan proses akuisisi dan pembentukan pengetahuan baru (knowledge creation) melalui penelitian dan proyek bersama, proses berbagi dan akuisisi pengetahuan melalui kegiatan belajar mengajar, kolaborasi, komunikasi, dan berbagi pengetahuan antar staf akademik, dan pengetahuan yang dimiliki tiap-tiap individu untuk dijadikan intangible asset ( $\mathrm{Al}$ Kurdi et al, 2018; Ramjeawon \& Rowley, 2017). Kegiatan belajar mengajar sebagai praktik sehari-hari dalam institusi 
pendidikan juga melibatkan proses knowledge transfer antara pengajar dan pelajar, dimana terdapat proses akuisisi pengetahuan dan informasi yang dilakukan peserta didik yang diperoleh dari pendidik (Alawamleh et al, 2020). Misi institusi pendidikan tinggi untuk membimbing, mengedukasi, meneliti, dan berbakti kepada sesama berhubungan secara langsung dengan kegiatan akuisisi, transfer, dan berbagi pengetahuan. Dengan demikian pembelajaran di institusi pendidikan dapat dilihat menggunakan pendekatan knowledge management (Chu, 2016; Fauzi et al., 2019).

Penelitian-penelitian

terdahulu menemukan pengelolaan pengetahuan memiliki pengaruh positif terhadap institusi pendidikan secara keseluruhan. Studi Al Kurdi et al(2018) menunjukkan aplikasi pengelolaan pengetahuan dalam institusi pendidikan berdampak positif pada kemajuan akademik perguruan tinggi. Dalam konteks pembelajaran di perguruan tinggi, pengelolaan pengetahuan dapat memfasilitasi pengembangan pengetahuan yang dapat digunakan untuk mengembangkan dan memperbaiki metode pembelajaran, kurikulum, dan strategi pelaksanaan sehingga proses pembelajaran menjadi efektif dan target pembelajaran dapat tercapai (Sahibzada, Jianfeng, Latif, \& Sahibzada, 2020). Fauzi et al (2019) dalam penelitiannya menemukan pemanfaatan pengetahuan melalui knowledge creation dan knowledge sharing dapat meningkatkan kolaborasi dan produktivitas akademik di tingkat perguruan tinggi, yang dapat dilihat dari semakin banyak jurnal, publikasi yang diterbitkan. Penelitian lain oleh Boateng et al (2014) di perguruan tinggi menemukan akuisisi pengetahuan dan proses pembelajaran dapat meningkatkan segi kompetitif mahasiswa untuk bisa bersaing di dunia kerja. Studi yang dilakukan Jain \& Gupta (2019) di perguruan tinggi menemukan bahwa penerapan manajemen pengetahuan yang meliputi proses akuisisi, berbagi, kolaborasi dan penyimpanan pengetahuan di perguruan tinggi dapat meningkatkan performa mahasiswa sekaligus meningkatkan efektivitas proses pembelajaran. Studi lain oleh Sahibzada et al (2020) menemukan pengelolaan pengetahuan di perguruan tinggi dapat meningkatkan nilai kompetitif perguruan tinggi tersebut. Dengan demikian, berdasarkan penelitian terdahulu, dapat dilihat pengaruh positif akuisisi pengetahuan dalam meningkatkan efektivitas proses pembelajaran.

Penelitian lain yang dilakukan Charband \& Navimipour (2018) dengan objek penelitian institusi pendidikan menunjukkan pentingnya peran individu, organisasi, dan teknologi pendukung untuk memudahkan mengakuisisi dan membagikan pengetahuan untuk kemajuan institusi pendidikan. Dengan demikian, dapat dilihat adanya beberapa faktor yang dapat mendorong atau menghambat proses akuisisi dan berbagi pengetahuan dalam organisasi.

\section{Faktor yang Berpengaruh Terhadap Akuisisi Pengetahuan}

Berdasarkan teori kognitif, proses pembelajaran merupakan proses internal, dimana terjadi proses memahami, mengolah informasi, analisis, dan mengaplikasikan pengetahuan dalam diri peserta didik / pembelajar. Berdasarkan teori kognitif, kemampuan peserta didik mempelajari dan menguasai materi selama proses pembelajaran dipengaruhi oleh aspek internal dan eksternal. Aspek internal meliputi persepsi / keyakinan dalam diri individu / pelajar. Aspek eksternal meliputi interaksi sosial, suasana pelajaran, kapabilitas dan kemampuan pengajar membuat suasana pembelajaran lebih interaktif dan konstruktif (Wisman, 2020).

Penelitian-penelitian terdahulu terhadap akusisi pengetahuan juga menunjukkan akuisisi pengetahuan dalam proses pembelajaran dapat didorong atau dihambat oleh tiga faktor utama, yaitu faktor individu, eksternal/organisasi, dan teknologi informasi komunikasi.

\section{Faktor Individu}

Individu punya peran krusial dalam penciptaan pengetahuan dalam organisasi karena pengetahuan dapat terbentuk dari interaksi yang dilakukan sesama individu atau antara individu dengan lingkungan (Thanki \& Thakar, 2018). Keberhasilan pengelolaan pengetahuan tidak lepas dari peran individu dalam organisasi yang mau untuk mencari, berbagi, dan memanfaatkan pengetahuan dari berbagai sumber untuk kemajuan 
perusahaan. Penelitian-penelitian terdahulu menemukan beberapa faktor individual yang dapat mendorong atau menghambat akuisisi pengetahuan dalam organisasi.

Bloice \& Burnett (2016) dalam penelitiannya menemukan kurangnya kesadaran individu untuk mengakuisisi pengetahuan baru, kurangnya waktu untuk belajar pengetahuan terbaru akibat beban kerja yang cukup besar sebagai penghambat akuisisi pengetahuan dalam organisasi dari perspektif individu. Penelitian Al Kurdi et al (2018) menemukan beberapa faktor individu lain yang menjadi penghambat akuisisi pengetahuan, antara lain tidak terbuka dengan ide baru, tidak mampu memanfaatkan teknologi, tidak suka berpikir out of the box, tidak suka bekerja sama dengan orang dan berkolaborasi, takut pengetahuannya diambil orang lain (Al-Kurdi et al., 2018). Penelitian lain oleh Charband \& Navimipour (2018) menunjukkan bahwa kemauan individu untuk mengakuisisi dan membagikan pengetahuan didorong oleh norma subjektif dan pandangan (perceived behaviour) terhadap pentingnya menambah pengetahuan baru. Studi Huang (2015) menemukan motivasi dan komitmen seseorang untuk terus mencari informasi dari berbagai media sebagai pendorong penginkatan akuisisi pengetahuan dalam perusahaan.

Penelitian Cantu \& Mondragon (2016) terhadap organisasi non-profit di Meksiko menunjukkan peran motivasi pribadi dan komitmen individu terhadap organisasi dalam membentuk perilaku akuisisi pengetahuan dalam organisasi. Penelitian lain oleh Carter et al (2020) terhadap proses pembelajaran menemukan bahwa keberhasilan pembelajaran terjadi jika ada motivasi kuat dari setiap pelajar untuk belajar daring, adanya ekspektasi dan tujuan belajar yang ingin dicapai para peserta didik, serta keinginan untuk selalu menambah pengetahuan baru. Hal ini juga sesuai dengan teori kognitif, dimana proses belajar juga dipengaruhi oleh faktor individu atau persepsi dalam diri individu. Berdasarkan penelitianpenelitian terdahulu, dapat dirumuskan hipotesis sebagai berikut:

H1. Faktor individu berpengaruh signifikan positif terhadap akuisisi pengetahuan.

\section{Faktor Teknologi}

Penelitian-penelitian terdahulu menunjukkan bahwa teknologi berperan dalam mendorong atau menghambat akuisisi pengetahuan dalam organisasi. Bloice \& Burnett (2016) dalam penelitiannya menemukan bahwa keberadaan teknologi memudahkan organisasi untuk mengambil, membagikan, mengkolaborasikan, dan menyimpan pengetahuan. Teknologi informasi dan komunikasi (ICT) yang update memudahkan organisasi dalam mengambil dan mengolah pengetahuan dan informasi dari berbagai sumber yang dapat digunakan untuk meningkatkan keunggulan bersaing (Cavaliere VIncenzo, Lombardi, \& Giustiniano, 2015; Al-Kurdi et al., 2018)).

Dalam konteks pendidikan, teknologi informasi berperan sebagai media yang memudahkan untuk mengakses, belajar, berkolaborasi, berinteraksi, evaluasi pembelajaran, serta meningkatkan kualitas akuisisi dan transfer pengetahuan. Dukungan teknologi informasi daring seperti open online course, elearning system, media penyimpanan daring dapat memfasilitasi akuisisi dan pembentukan pengetahuan yang menunjang proses pembelajaran (Jain \& Gupta, 2019; Shih \& Tsai, 2016), Veer Ramjeawon \& Rowley (2017) dalam penelitiannya menemukan pemanfaatan teknologi seperti digital library dan akses jurnal digital dapat memudahkan proses akuisisi pengetahuan di perguruan tinggi. Pemanfaatan teknologi juga mendukung proses pembelajaran yang berdampak pada peningkatan kinerja akademik, inovasi, dan kemudahan proses belajar mengajar (Jain \& Gupta, 2019). Oleh karena itu, dapat disimpulkan bahwa infrastruktur teknologi informasi punya pengaruh positif terhadap proses akuisisi pengetahuan yang dapat dirumuskan dalam hipotesis berikut:

H2. Infrastruktur teknologi informasi berpengaruh signifikan positif terhadap efektivitas pembelajaran daring

\section{Faktor Organisasi}

Keberhasilan pengelolaan pengetahuan dalam organisasi tidak lepas dari peran organisasi 
secara keseluruhan sebagai wadah berkumpulnya para individu tujuan sama yang ingin dicapai. Penelitian-penelitian terdahulu menemukan bahwa faktor organisasi punya peran dalam mendorong atau menghambat akuisisi pengetahuan dalam organisasi.

Al Kurdi et al (2018) dalam penelitiannya menemukan beberapa faktor yang mendorong atau menghambat akuisisi dan pemanfaatan pengetahuan dari perspektif organisasi yaitu (1) tujuan organisasi; (ii) faktor kepemimpinan berupa dukungan, komitmen, keputusan dari pimpinan organisasi dapat berpengaruh terhadap perilaku akuisisi pengetahuan; (iii) koordinasi dan kolaborasi antar sesama individu dalam perusahaan; (iv) ada tidaknya rasa saling percaya antar anggota perusahaan untuk berkolaborasi Bersama; (v) faktor birokrasi : birokrasi dan jalur komunikasi dalam organisasi yang fleksibel/rigid dapat mendukung atau menghambat akuisisi pengetahuan dalam perusahaan; (vi) faktor finansial, misalnya dukungan finansial berupa penghargaan, insentif kepada karyawan yang mau mengakuisisi pengetahuan baru, serta dana untuk mengadakan training dan investasi teknologi informasi dapat menjadi penghambat atau pendorong pengelolaan pengetahuan. Penelitian lain oleh Cantu \& Mondragon (2016) menunjukkan budaya organisasi menjadi faktor organisasi yang berperan dalam proses akuisisi pengetahuan di organisasi. Organisasi yang terbuka dan siap mengeksplorasi ide-ide baru memudahkan organisasi untuk mengakuisisi pengetahuan baru. Penelitian oleh Owusu-Manu et al (2017) juga menemukan faktor budaya organisasi yang inovatif dan secara aktif mendorong dan mendukung para anggotanya untuk mencari informasi dan pengetahuan baru secara mandiri sebagai pendorong peningkatan akuisisi pengetahuan dalam organisasi (Owusu Manu, John Edwards, Parn, \& Antwi-Afari, 2017; Supermane \& Mohd Tahir, 2018). Hal ini juga didukung oleh Adeinat \& Abdulfatah (2019) yang menemukan bahwa budaya organisasi yang inovatif, berani mengambil resiko dan memberdayakan anggota lewat pelatihan, akan memudahkan fasilitasi proses belajar dalam organisasi. Sebaliknya, penelitian Fauzi et al (2018) menemukan bahwa budaya organisasi yang tidak berpikir kritis dan kreatif dapat menghambat implementasi dan pengelolaan pengetahuan dalam organisasi

Iqbal et al (2018) menemukan faktor kepemimpinan organisasi, budaya organisasi, pemberian insentif kepada anggota organisasi sebagai faktor organisasi yang berpengaruh terhadap akuisisi pengetahuan dalam perusahaan. Penelitian ini didukung oleh penelitian Chu (2016) yang menemukan efektivitas kepemimpinan organisasi dapat meningkatkan kepercayaan dan rasa memiliki setiap anggota organisasi sehingga memudahkan proses akuisisi dan pengelolaan pengetahuan dalam organisasi. Penelitian lain oleh Bloice \& Burnett (2016) menunjukkan kurangnya pelatihan dan kesempatan yang memadai sebagai penghambat akuisisi pengetahuan dari perspektif organisasi. Penelitian Veer Ramjeawon \& Rowley (2017) terhadap perguruan tinggi menemukan kapabilitas tenaga akademik, dan insentif yang diberikan pimpinan sebagai faktor organisasi yang mendukung terjadinya akuisisi dan pembentukan pengetahuan. Selain itu, visi yang tidak mendukung pemanfaatan pengetahuan baru, kurangnya dana dan resources pendukung, beban kerja yang terlalu berat, tidak adanya proyek yang melibatkan kolaborasi dan kerja sama antar departemen menjadi faktor organisasi penghambat akuisisi pengetahuan di perguruan tinggi (Veer Ramjeawon \& Rowley, 2017). Menurut teori kognitif, proses pembelajaran dipengaruhi oleh kapabilitas pengajar dalam meningkatkan interaksi dan menciptakan suasana pembelajaran yang konstruktif (Wisman, 2020). Berdasarkan penelitian terdahulu menggunakan konteks perguruan tinggi, dapat dirumuskan hipotesis sebagai berikut:

H3. Faktor universitas berpengaruh signifikan positif terhadap akuisisi pengetahuan.

Berdasarkan studi literatur yang telah dilakukan, terdapat 3 faktor utama yang dapat berpengaruh terhadap akuisisi pengetahuan, yaitu faktor individu, infrastruktur IT, dan faktor organisasi. Ketiga variabel tersebut masing-masing dibagi lagi menjadi sejumlah manifes atau subfaktor yang lebih rinci. Tidak semua manifes digunakan dalam penelitian ini, karena tidak semua 
variabel manifes tersebut relevan dengan konteks perguruan tinggi. Berdasarkan hasil penelitian terdahulu yang menunjukkan hubungan antara akuisisi pengetahuan dan pembelajaran daring, dengan konteks pembelajaran daring, hubungan antara akuisisi pengetahuan dan efektivitas pembelajaran daring dapat dirumuskan dalam hipotesis berikut:

H4. Akuisisi pengetahuan berpengaruh signifikan positif terhadap efektivitas pembelajaran daring

Model penelitian yang dapat dibuat berdasarkan studi literatur, sebagai berikut:

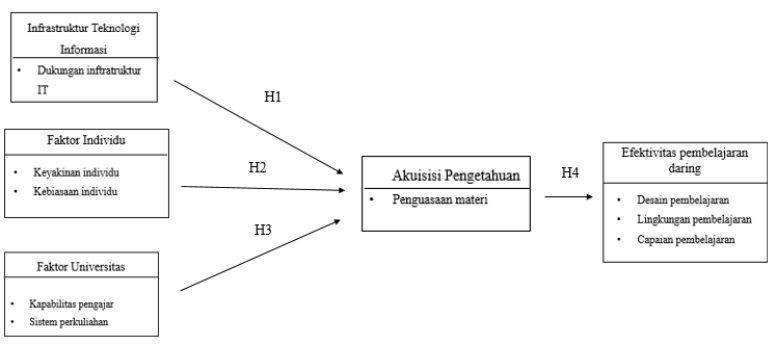

Gambar 1. Model Penelitian

\section{METODOLOGI}

Penelitian ini menggunakan metodologi penelitian kuantitatif berupa survei dan triangulasi metode, menggunakan studi kasus pada mahasiswa PSIAB Unpar, Bandung. Survei dilakukan melalui penyebaran kuesioner kepada responden penelitian. Pemilihan metode kuantitatif ditujukan agar diperoleh hasil yang lebih objektif, terpercaya, dan andal (Clark \& Creswell, 2015).

Triangulasi dilakukan dengan melakukan triangulasi metode yaitu melalui proses wawancara dengan mewawancarai expert di bidang pendidikan, dosen yang mengajar kuliah daring, dan mahasiswa untuk memperoleh gambaran hasil penelitian yang lebih utuh, andal, membandingkan hasil kuesioner dengan fakta lapangan dan pendapat ahli agar diperoleh hasil penelitian yang lebih valid.

Target penelitian ini adalah mahasiswa PSIAB, dengan sampel penelitian sejumlah minimal 261 (Clark \& Creswell, 2015). Pemilihan sampel penelitian sejumlah minimal 261 dikarenakan jumlah populasi penelitian yang cukup besar, kurang lebih 750, sehingga membutuhkan jumlah sampel yang dapat mewakili populasi. Dengan menggunakan rumus Slovin untuk menentukan jumlah sampel minimal, menggunakan taraf signifikansi sebesar 0,05, akan diperoleh jumlah sampel minimal 261 (Clark \& Creswell, 2015). Sampel dalam penelitian ini berupa mahasiswa aktif PSIAB Unpar, Bandung. Pemilihan sampel didasarkan pada tujuan penelitian, sehingga dapat dikatakan teknik pengambilan sampel yang dimaksud di penelitian ini adalah purposive sampling, karena sampel penelitian telah ditetapkan peneliti berdasarkan sejumlah kriteria, yaitu mahasiswa aktif yang berkuliah di PSIAB Unpar, Bandung, tahun pertama sampai keempat.

Pemilihan mahasiswa aktif PSIAB sebagai sampel penelitian didasari karena mahasiswa tersebut sudah mengikuti aktivitas perkuliahan selama lebih dari dua semester, telah mengetahui budaya dan metode pembelajaran dalam universitas, serta telah mengikuti aktivitas perkuliahan baik secara luring, maupun secara daring sehingga dapat menggambarkan kondisi perkuliahan daring di PSIAB Unpar.

Jenis data pada penelitian ini berupa data primer. Data primer diperoleh lewat penyebaran kuesioner kepada mahasiswa PSIAB yang menjadi responden penelitian Pengolahan data terhadap model penelitian yang telah dibuat dilakukan dengan tahapan berikut :

1. Dilakukan uji hipotesis secara kuantitatif melalui kuesioner yang disebarkan kepada mahasiswa tingkat dua, tiga, dan empat PSIAB Unpar, Bandung, dengan menggunakan IBM SPSS Software untuk menguji validitas dan reliabilitas variabel yang telah dibuat serta uji hipotesis. Dilakukan uji model berbasis regresi linier karena sampel yang digunakan lebih dari 100.

2. Dilakukan analisis lanjutan terhadap data kuantitatif yang sudah diperoleh untuk memperoleh validitas yang lebih tinggi menggunakan metode triangulasi. Pengujian triangulasi ini ditujukan kepada pihak pemerintah dan akademisi.

\section{Operasionalisasi Variabel}

Penelitian ini menggunakan lima variabel yang digunakan dalam uji hipotesis, seperti tampak pada tabel 1 berikut ini: 
Tabel 1.Operasionalisasi Variabel

\begin{tabular}{|c|c|c|c|c|}
\hline No & Variabel & Manifes & Indikator & \begin{tabular}{|c|} 
Skala \\
Pengukur \\
an \\
\end{tabular} \\
\hline \multirow[t]{6}{*}{1} & \multirow{6}{*}{$\begin{array}{l}\text { Efektivi } \\
\text { tas } \\
\text { Pembela } \\
\text { jaran } \\
\text { Daring }\end{array}$} & \multirow{2}{*}{$\begin{array}{l}\text { Desain } \\
\text { Pembela } \\
\text { jaran }\end{array}$} & $\begin{array}{l}\text { Perancangan } \\
\text { Materi }\end{array}$ & $\begin{array}{c}1-5 \\
\text { (Likert) } \\
\end{array}$ \\
\hline & & & $\begin{array}{l}\text { Penyampaian } \\
\text { materi }\end{array}$ & $\begin{array}{c}1-5 \\
\text { (Likert) }\end{array}$ \\
\hline & & \multirow{2}{*}{$\begin{array}{l}\text { Capaian } \\
\text { Pembela } \\
\text { jaran }\end{array}$} & $\begin{array}{l}\text { Penguasaan } \\
\text { materi }\end{array}$ & $\begin{array}{c}1-5 \\
\text { (Likert) }\end{array}$ \\
\hline & & & Aspek kognitif & $\begin{array}{c}1-5 \\
\text { (Likert) }\end{array}$ \\
\hline & & \multirow{2}{*}{$\begin{array}{l}\text { Lingkun } \\
\text { gan } \\
\text { Pembela } \\
\text { jaran }\end{array}$} & $\begin{array}{l}\text { Suasana } \\
\text { pembelajaran }\end{array}$ & $\begin{array}{c}1-5 \\
\text { (Likert) } \\
\end{array}$ \\
\hline & & & Fleksibilitas & $\begin{array}{c}1-5 \\
\text { (Likert) }\end{array}$ \\
\hline \multirow[t]{2}{*}{2} & \multirow{2}{*}{$\begin{array}{l}\text { Infrastru } \\
\text { ktur } \\
\text { Teknolo } \\
\text { gi } \\
\text { Informa } \\
\text { si } \\
\end{array}$} & \multirow{2}{*}{$\begin{array}{l}\text { Dukung } \\
\text { an } \\
\text { Infrastru } \\
\text { ktur IT }\end{array}$} & Aksesibilitas & $\begin{array}{c}1-5 \\
\text { (Likert) }\end{array}$ \\
\hline & & & Pengembangan IT & $\begin{array}{c}1-5 \\
\text { (Likert) }\end{array}$ \\
\hline \multirow[t]{3}{*}{3} & \multirow[t]{3}{*}{$\begin{array}{l}\text { Faktor } \\
\text { Individu }\end{array}$} & \multirow[t]{2}{*}{$\begin{array}{l}\text { Keyakin } \\
\text { an } \\
\text { Individu }\end{array}$} & $\begin{array}{l}\text { Keyakinan } \\
\text { terhadap } \\
\text { pentingnya } \\
\text { pembelajaran } \\
\text { daring }\end{array}$ & $\begin{array}{c}1-5 \\
\text { (Likert) }\end{array}$ \\
\hline & & & $\begin{array}{l}\text { Motivasi belajar } \\
\text { daring }\end{array}$ & $\begin{array}{c}1-5 \\
\text { (Likert) }\end{array}$ \\
\hline & & $\begin{array}{l}\text { Kebiasa } \\
\text { an } \\
\text { individu }\end{array}$ & $\begin{array}{l}\text { Kebiasaan belajar } \\
\text { daring }\end{array}$ & $\begin{array}{c}1-5 \\
\text { (Likert) }\end{array}$ \\
\hline \multirow[t]{3}{*}{4} & \multirow[t]{3}{*}{$\begin{array}{l}\text { Faktor } \\
\text { Universi } \\
\text { tas }\end{array}$} & $\begin{array}{l}\text { Kapabili } \\
\text { tas } \\
\text { Pengajar }\end{array}$ & $\begin{array}{l}\text { Literasi teknologi } \\
\text { daring }\end{array}$ & $\begin{array}{c}1-5 \\
\text { (Likert) }\end{array}$ \\
\hline & & \multirow[t]{2}{*}{$\begin{array}{l}\text { Sistem } \\
\text { Perkulia } \\
\text { han }\end{array}$} & $\begin{array}{l}\text { Dukungan } \\
\text { terhadap } \\
\text { pembelajaran } \\
\text { daring } \\
\end{array}$ & $\begin{array}{c}1-5 \\
\text { (Likert) }\end{array}$ \\
\hline & & & $\begin{array}{l}\text { Pengembangan } \\
\text { kurikulum daring }\end{array}$ & $\begin{array}{c}1-5 \\
\text { (Likert) }\end{array}$ \\
\hline 5 & $\begin{array}{l}\text { Akuisisi } \\
\text { Pengeta } \\
\text { huan }\end{array}$ & $\begin{array}{l}\text { Penguas } \\
\text { aan } \\
\text { materi }\end{array}$ & $\begin{array}{l}\text { Kemampuan } \\
\text { memahami dan } \\
\text { menguasai materi } \\
\text { perkuliahan } \\
\text { daring }\end{array}$ & $\begin{array}{c}1-5 \\
\text { (Likert) }\end{array}$ \\
\hline
\end{tabular}

Lima variabel yang digunakan dalam penelitian ini, antara lain efektivitas pembelajaran daring, infrastruktur teknologi informasi, faktor individu, faktor universitas, dan akuisisi pengetahuan. Kelima variabel tersebut diukur lebih lanjut melalui sejumlah indikator yang dituangkan melalui butir-butir kuesioner. Skala pengukuran kuesioner menggunakan skala Likert 1-5 dengan range 1 berarti sangat tidak setuju terhadap pernyataan kuesioner dan 5 berarti sangat setuju terhadap pernyataan kuesioner.

\section{Efektivitas Pembelajaran Daring}

Efektivitas pembelajaran daring mengacu pada bagaimana proses belajar mengajar secara daring berlangsung sehingga memenuhi kompetensi dan target pembelajran yang diharapkan. Efektivitas pembelajaran daring diukur menggunakan variabel manifes desain pembelajaran, capaian pembelajaran, lingkungan pembelajaran (Alawamleh et al., 2020; Carter et al., 2020; Veer Ramjeawon \& Rowley, 2020)

\section{Infrastruktur Teknologi Informasi}

Infrastruktur teknologi merupakan pemanfaatan teknologi informasi dan berbagai media digital yang dapat menunjang kegiatan perkuliahan secara daring. Dalam penelitian ini, teknologi diukur menggunakan indikator dukungan teknologi informasi (Iqbal et al., 2019; Jain \& Gupta, 2019; Veer Ramjeawon \& Rowley, 2017).

\section{Faktor Individu}

Faktor individu mengacu pada peran individu yaitu mahasiswa yang melakukan akuisisi pengetahuan secara daring dari dosen. Indikator yang digunakan dalam penelitian ini dengan konteks universitas adalah keyakinan individu serta kebiasaan individu belajar dari sumber daring (Al-Kurdi et al., 2018; Alawamleh et al., 2020; Carter et al., 2020; Thani \& Mirkamali, 2018; Veer Ramjeawon \& Rowley, 2017).

\section{Faktor Universitas}

Faktor Universitas mengacu pada peran universitas sebagai organisasi yang memiliki pengaruh terhadap kegiatan belajar mengajar secara daring, dimana organisasi dalam konteks penelitian ini adalah dosen dalam universitas yang berperan membagikan materi perkuliahan atau pengetahuan kepada mahasiswa. Indikator yang digunakan dalam variabel ini adalah kapabilitas pengajar memanfaatkan teknologi dan sistem perkuliahan (Al-Kurdi et al., 2018; Krishnaswamy, Hossain, Kavigtha, \& Nagaletchimee, 2019; Veer Ramjeawon \& Rowley, 2017; Zapata Cantu \& Mondragon, 2016). 


\section{Akuisisi pengetahuan}

Akuisisi pengetahuan merupakan kemampuan organisasi dan/ atau individu untuk mencari, mengambil, dan mengkolaborasikan pengetahuan eksternal dengan pengetahuan internal untuk memperkaya pengetahuan dan meningkatkan keunggulan bersaing (Duarte Alonso et al., 2019; Papa, Dezi, Gregori, Mueller, \& Miglietta, 2018). Akuisisi pengetahuan dalam konteks penelitian ini merupakan kemampuan mahasiswa untuk menyerap dan menguasai materi pembelajaran yang disampaikan dosen selama perkuliahan daring, yang dapat diukur dari pemahaman dan penguasaan materi dari sumber eksternal daring, misalnya dari media platform daring, e-learning (Boateng et al., 2014; Iqbal et al., 2019).

\section{PEMBAHASAN DAN HASIL PENELITIAN}

\section{Hasil Penelitian}

Penelitian ini dilakukan kepada mahasiswa PSIAB Unpar, Bandung. Pengumpulan data dilakukan menggunakan purposive sampling, dimana kuesioner disebarkan langsung kepada responden yang merupakan mahasiswa PSIAB di berbagai tingkat. Kriteria pemilihan responden adalah mahasiswa aktif PSIAB Unpar yang telah mengikuti kegiatan perkuliahan baik secara tatap muka maupun daring. Responden yang bersedia mengisi kuesioner tersebut didominasi oleh mahasiswa PSIAB di tahun kedua dan ketiga. Profil responden secara lengkap dapat dilihat pada tabel berikut

Tabel 2.Profil Responden

\begin{tabular}{|c|c|c|}
\hline Profil Responden & $\mathrm{n}$ & $\%$ \\
\hline \multicolumn{3}{|l|}{ Jenis Kelamin } \\
\hline Laki Laki & 151 & 51,2 \\
\hline Perempuan & 144 & 48,8 \\
\hline \multicolumn{3}{|l|}{ Jenjang Perkuliahan } \\
\hline Tahun pertama (Semester $1 \& 2$ ) & 66 & 22,4 \\
\hline Tahun kedua (Semester 3\& 4) & 96 & 32,5 \\
\hline Tahun ketiga (Semester 5 \& 6) & 73 & 24,7 \\
\hline Tahun keempat (Semester $7 \& 8$ ) & 46 & 15,6 \\
\hline Lebih dari empat tahun & 14 & 4,8 \\
\hline \multicolumn{3}{|c|}{ Jumlah Mata Kuliah yang Diambil } \\
\hline $1-3$ & 60 & 4,1 \\
\hline $4-6$ & 12 & 20,3 \\
\hline$>6$ & 223 & 75,6 \\
\hline
\end{tabular}

Pengolahan data dilakukan dengan melakukan uji validitas dan uji reliabilitas terlebih dahulu. Uji validitas dilakukan untuk menguji kevalidan item kuesioner sebagai alat ukur untuk menguji variabel penelitian. Syarat validitas data adalah nilai $r$ hitung $>r$ tabel pada $n=295$ dan signifikansi 2 tailed $<0,05$. Hasil uji validitas di SPSS menunjukkan semua item kuesioner valid. Uji reliabilitas dilakukan untuk menguji konsistensi kuesioner jika pengukuran menggunakan kuesioner tersebut dilakukan secara berulang. Syarat uji reliabilitas adalah nilai cronbach alpha >0,7. Hasil uji reliabilitas menunjukan bahwa kuesioner memiliki konsistensi yang baik atau reliabel. Selanjutnya dilakukan uji hipotesis melalui proses regresi linier menggunakan variabel mediating di SPSS. Syarat hubungan antar variabel berpengaruh signifikan adalah memiliki nilai signifikansi $<0,05$. Hasil regresi dapat dilihat pada tabel berikut

\begin{tabular}{|c|c|c|c|c|c|}
\hline Variabel & $\alpha$ & $\begin{array}{c}\text { signifik } \\
\text { ansi }\end{array}$ & $\begin{array}{c}\text { Koefisi } \\
\text { en } \beta\end{array}$ & $\begin{array}{c}\mathrm{R} \\
\text { squared }\end{array}$ & Hubungan \\
\hline $\mathrm{IT} \rightarrow \mathrm{AK}$ & 0,05 & 0,040 & $-0,091$ & \multirow[t]{3}{*}{0,637} & $\begin{array}{c}\text { Berpengaruh } \\
\text { signifikan }\end{array}$ \\
\hline FI $\rightarrow$ AK & 0,05 & 0,000 & 0,746 & & $\begin{array}{c}\text { Berpengaruh } \\
\text { signifikan }\end{array}$ \\
\hline $\mathrm{FU} \rightarrow \mathrm{AK}$ & 0,05 & 0,001 & 0,157 & & $\begin{array}{c}\text { Berpengaruh } \\
\text { signifikan }\end{array}$ \\
\hline IT $->$ EPD & 0,05 & 0,001 & 0,152 & \multirow[t]{4}{*}{0,648} & $\begin{array}{c}\text { Berpengaruh } \\
\text { signifikan }\end{array}$ \\
\hline FI $->$ EPD & 0,05 & 0,000 & 0,242 & & $\begin{array}{c}\text { Berpengaruh } \\
\text { signifikan }\end{array}$ \\
\hline $\begin{array}{c}\text { FU -> } \\
\text { EPD }\end{array}$ & 0,05 & 0,005 & 0,133 & & $\begin{array}{c}\text { Berpengaruh } \\
\text { signifikan }\end{array}$ \\
\hline $\begin{array}{c}\mathrm{AK}-> \\
\mathrm{EPD}\end{array}$ & 0,05 & 0,000 & 0,432 & & $\begin{array}{c}\text { Berpengaruh } \\
\text { signifikan }\end{array}$ \\
\hline
\end{tabular}

Hasil regresi menunjukkan variabel independen Infrastruktur Teknologi Informasi, Faktor Individu, Faktor Universitas berpengaruh signifikan langsung terhadap variabel akuisisi pengetahuan karena memiliki nilai signifikansi $<0,05$. Nilai $R$ squared sebesar 0,637 menunjukkan pengaruh variabel independen Infrastruktur Teknologi Informasi, Faktor Individu, Faktor Universitas sebesar $63,7 \%$ terhadap variabel dependen Akuisisi pengetahuan dan 36,3\% sisanya dipengaruhi variabel lain yang tidak diteliti. Selain itu, variabel Infrastruktur Teknologi Informasi, Faktor Individu, Faktor Universitas, Akuisisi 
Pengetahuan berpengaruh signifikan terhadap variabel Efektivitas Pembelajaran Daring karena memiliki signifikansi $<0,05$. Nilai $R$ squared sebesar 0,648 menunjukkan bahwa variabel Infrastruktur Teknologi Informasi, Faktor Individu, Faktor Universitas, Akuisisi Pengetahuan berpengaruh sebesar $64,8 \%$ terhadap variabel Efektivitas Pembelajaran Daring dan 35,2\% sisanya dipengaruhi variabel lain yang tidak diteliti. Hubungan antar variabel dapat digambarkan pada model berikut.

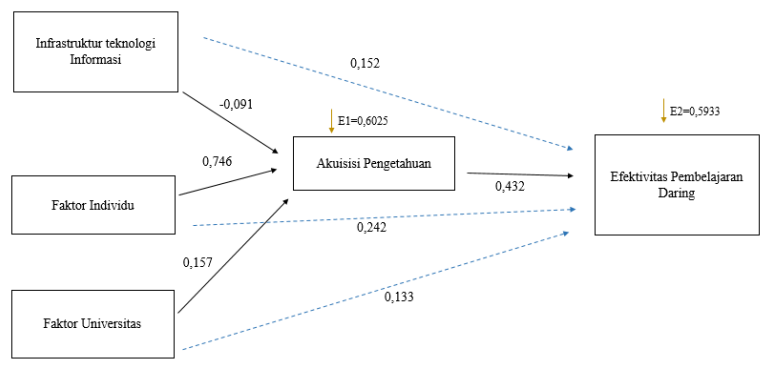

Gambar 2. Model Hubungan Antar Variabel

Analisis jalur dilakukan untuk menentukan peran variabel mediator Akuisisi Pengetahuan terhadap hubungan antara variabel independen Infrastruktur Teknologi Informasi, Faktor Individu, Faktor Universitas dengan variabel dependen Efektivitas Pembelajaran Daring. Dengan membandingkan perolehan koefisien $\beta$ dengan dan tanpa variabel mediator, diperoleh hasil yang dapat dilihat pada tabel berikut:

Tabel 4. Hasil Regresi Linear dengan Variabel Mediating
\begin{tabular}{|l|c|c|l|}
\hline Jalur & $\begin{array}{c}\beta \text { dengan } \\
\text { variabel } \\
\text { mediator } \\
\text { AK }\end{array}$ & $\begin{array}{c}\beta \text { tanpa } \\
\text { variabel } \\
\text { mediator } \\
\text { AK }\end{array}$ & \multicolumn{1}{|c|}{ Interpretasi } \\
\hline $\begin{array}{l}\text { IT } \rightarrow \text { AK } \\
\rightarrow \text { EPD }\end{array}$ & $-0,03$ & 0,152 & $\begin{array}{l}\text { Variabel AK tidak } \\
\text { memediasi hubungan } \\
\text { IT } \rightarrow \text { EPD }\end{array}$ \\
\hline $\begin{array}{l}\text { FI } \rightarrow \text { AK - } \\
>\text { EPD }\end{array}$ & 0,322 & 0,242 & $\begin{array}{l}\text { Variabel AK memediasi } \\
\text { hubungan FI } \rightarrow \text { EPD }\end{array}$ \\
\hline $\begin{array}{l}\text { FU } \rightarrow \text { AK- } \\
>\text { EPD }\end{array}$ & 0,068 & 0,133 & $\begin{array}{l}\text { Variabel AK tidak } \\
\text { memediasi hubungan } \\
\text { FU } \rightarrow \text { EPD }\end{array}$ \\
\hline
\end{tabular}

\section{Hubungan Infrastruktur Teknologi Informasi, Akuisisi Pengetahuan, dan Efektivitas Pembelajaran Daring}

Regresi linier yang dilakukan terhadap variabel independen infrastruktur teknologi informasi, Akuisisi Pengetahuan, dan variabel dependen Efektivitas Pembelajaran Daring, menghasilkan hubungan antara variabel yang digambarkan pada model berikut.

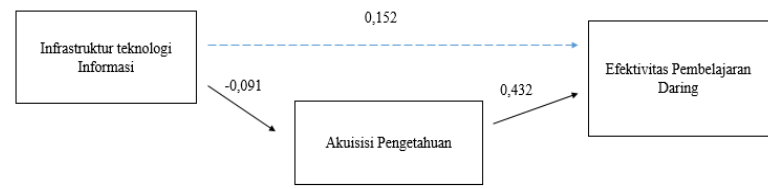

Gambar 3. Model Hubungan Infrastruktur Teknologi Informasi, Akuisisi Pengetahuan, dan Efektivitas Pembelajaran Daring

Hasil regresi menunjukkan variabel infrastruktur teknologi informasi berpengaruh signifikan positif terhadap variabel efektivitas pembelajaran daring. Hasil tersebut menunjukkan keberadaan infrastruktur teknologi informasi dapat mendorong peningkatan efektivitas pembelajaran daring. Hal ini dapat disebabkan karena infrastruktur teknologi informasi, yang di dalamnya meliputi peralatan, jaringan, dan keandalan sistem internal berperan penting untuk menunjang serta mewujudkan proses pembelajaran daring. Tanpa dukungan sistem teknologi informasi yang andal, proses pembelajaran daring jarak jauh tidak dapat berlangsung optimal. Teknologi informasi yang user friendly memudahkan terciptanya smart classroom yang dapat meng-engage baik dosen maupun mahasiswa agar terlibat dalam proses belajar mengajar yang interaktif dan konstruktif. Hal ini didukung pula oleh penelitian Zaheer \& Munir (2020) yang menujukkan peran teknologi informasi untuk menciptakan ruang virtual yang memungkinkan terjadinya interaksi antara dosen dan mahasiswa untuk mendukung efektivitas proses pembelajaran daring jarak jauh. Proses pembelajaran saat ini tidak lepas dari peran penting teknologi untuk memperluas pemahaman dan pengetahuan sekaligus memperbaiki sistem pembelajaran agar tujuan proses pembelajaran dapat tercapai (Alawamleh et al., 2020). Hal ini didukung dari hasil wawancara kepada akademisi yaitu:

"Tidak dapat dipungkiri, infrastruktur teknologi informasi menjadi faktor esensial yang mendukung kelancaran proses perkuliahan daring agar berjalan maksimal" 
Hasil analisis jalur berdasarkan nilai $\beta$ menunjukkan hubungan variabel Infrastruktur teknologi informasi terhadap efektivitas pembelajaran daring secara langsung $(\beta=-0,03)$ lebih besar daripada pengaruh variabel infrastruktur teknologi informasi terhadap efektivitas pembelajaran daring yang dimediasi variabel Akuisisi Pengetahuan $(\beta=0,152)$. Hal ini menunjukkan pengaruh infrastruktur teknologi informasi terhadap efektivitas pembelajaran daring tidak dimediasi proses akuisisi pengetahuan terlebih dahulu. Hal ini sesuai dengan peran langsung infrastruktur teknologi informasi sebagai tools atau supporting system untuk mengorganisir menunjang, meningkatkan aksesibilitas proses pembelajaran daring agar berlangsung efektif dan optimal (Al-Kurdi et al., 2018; Jain \& Gupta, 2019; Veer Ramjeawon \& Rowley, 2020).

Hasil regresi juga menunjukkan hasil variabel infrastruktur teknologi informasi berpengaruh signifikan negatif terhadap akuisisi pengetahuan, dapat dilihat dari nilai koefisien $\beta$ yang negatif. Menurut penelitian terdahulu yang dilakukan Nair et al (2019) dan Kaba et al (2020) teknologi informasi memudahkan organisasi dalam mengakuisisi, menciptakan, dan menyimpan pengetahuan sehingga berpengaruh positif terhadap proses akuisisi pengetahuan. Penelitian lain oleh Veer Ramjeawon et al (2020) menunjukkan infrastruktur teknologi informasi memberikan kemudahan bagi universitas untuk berkomunikasi, networking, memudahkan akses sumber referensi digital secara fleksibel. Pengaruh negatif Infrastruktur Teknologi Informasi terhadap proses akuisisi pengetahuan oleh mahasiswa selama proses perkuliahan daring menunjukkan infrastruktur IT sebagai pendukung proses pembelajaran daring justru menyulitkan mahasiswa untuk memahami materi pembelajaran daring yang disampaikan dosen. Hal ini dapat disebabkan karena menurut hasil kuesioner yang ditujukan kepada responden mahasiswa, masih terdapat permasalahan infrastruktur IT yang berkaitan dengan kesulitan akses dan ketidakstabilan koneksi, menyebabkan materi pembelajaran lebih sulit diakses dan menyulitkan mahasiswa dalam memahami dan mengakuisisi pengetahuan dari dosen. Di samping, itu perubahan metode pembelajaran dari tatap muka langsung menjadi daring secara mendadak dan tanpa persiapan sebelumnya menyebabkan pemanfaatan teknologi tidak membuat proses pemahaman materi perkuliahan lebih optimal (Kaba et al, 2019). Penelitian yang dilakukan Nair et al (2019) menggunakan objek penelitian perusahaan yang sudah memiliki literasi teknologi, sehingga hasilnya tentu dapat berbeda pada konteks institusi pendidikan yang terpaksa menerapkan teknologi untuk membantu proses perkuliahan daring.

\section{Hubungan Faktor Individu, Akuisisi Pengetahuan, dan Efektivitas Pembelajaran Daring}

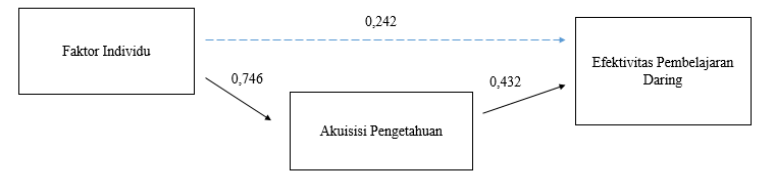

Gambar 4. Model Hubungan Faktor Individu, Akuisisi Pengetahuan, dan Efektivitas Pembelajaran Daring

Hasil regresi antara variabel independen faktor individu dan variabel dependen efektivitas pembelajaran daring menunjukkan bahwa faktor individu berpengaruh signifikan positif terhadap efektivitas pembelajaran daring. Selain itu, diperoleh hasil bahwa faktor individu turut berpengaruh signifikan positif terhadap akuisisi pengetahuan. Hal ini disebabkan karena keberhasilan pembelajaran daring tidak lepas dari peran individu (mahasiswa) sebagai pengakuisisi pengetahuan dari dosen dalam proses belajar mengajar. Faktor individu diukur menggunakan indikator keyakinan individu terhadap perkuliahan daring dan kebiasaan individu. Mahasiswa yang meyakini pentingnya proses pembelajaran daring untuk pengembangan dirinya akan lebih mudah menjaga fokus dan antusiasme selama mengikuti proses pembelajaran daring sekaligus memudahkan menguasai materi dibandingkan mahasiswa yang merasa pembelajaran daring tidak penting. Adanya motivasi dari dalam diri mahasiswa untuk mencapai tujuan perkuliahan daring akan memudahkan mahasiswa menguasai materi dan berpartisipasi aktif selama proses pembelajaran daring sehingga tujuan pembelajaran daring dapat tercapai (Alawamleh et al., 2020; Watjatrakul, 2016). Hal ini juga didukung oleh 
penelitian Zaheer \& Munir (2020) yang menemukan bahwa self motivation dan pola pikir pelajar menjadi salah satu kunci kesuksesan perkuliahan daring, serta penelitian Kaba et al (2020) dan Veeramjeawon et al (2020) yang menunjukkan kegemaran belajar dari berbagai sumber daring, misalnya jurnal digital, e-learning akan memudahkan seseorang mengakuisisi dan menguasai informasi yang diperoleh dari sumber daring (Alawamleh et al, 2020). Lebih lanjut berdasarkan hasil triangulasi kepada akademisi:

"Motivasi berperan penting dalam proses pembelajaran. Motivasi mahasiswa untuk mengikuti kuliah daring akan menentukan apakah proses proses pembelajaran hanya menjadi proses yang langsung berlalu, atau menjadi proses yang dapat meningkatkan kemampuan dan kompetensi diri."

Dengan demikian, dapat dilihat pengaruh positif faktor individu (keyakinan individu dan kebiasaan individu) terhadap akuisisi pengetahuan oleh mahasiswa dan efektivitas pembelajaran daring.

Berdasarkan perolehan nilai $\beta$, pengaruh faktor individu terhadap efektivitas pembelajaran daring yang dimediasi akuisisi pengetahuan ( $\beta=0,322$ ) lebih besar daripada pengaruh faktor individu terhadap efektivitas pembelajaran daring secara langsung $(\beta=0,242)$. Hal ini menunjukkan variabel akuisisi pengetahuan memediasi hubungan faktor individu dengan efektivitas pembelajaran daring. Jika dibandingkan dengan kedua variabel lain, variabel infrastruktur teknologi informasi dan faktor universitas tidak membutuhkan variabel mediator akuisisi pengetahuan untuk mempengaruhi efektivitas pembelajaran daring. Hal ini dapat disebabkan karena dalam konteks akuisisi pengetahuan, akuisisi pengetahuan tidak dapat berhasil tanpa peran individu/ mahasiswa sebagai pengakuisisi pengetahuan yang disampaikan dosen (faktor eksternal) dan didukung oleh infrastruktur teknologi informasi, untuk meningkatkan efektivitas pembelajaran daring. Sekalipun sudah didukung oleh keandalan infrastruktur IT dan kapabilitas dosen, tanpa dorongan dari dalam individu, proses akuisisi pengetahuan tidak dapat berjalan maksimal (Carter et al., 2020; Huang, 2015). Hal ini juga didukung hasil wawancara sebagai berikut:

"Kemampuan akuisisi pengetahuan selama perkuliahan daring sangat tergantung dari pribadi masing-masing mahasiswa, apakah mereka merasa materi kuliah tersebut menarik dan berguna buat mereka atau tidak. Jika memang mahasiswa tertarik dan merasa kuliah daring tersebut penting untuk dirinya, secara sadar mereka akan tetap menjaga fokus dan mudah untuk menguasai setiap materi perkuliahan daring dengan baik. Kemampuan akuisisi pengetahuan selama kuliah daring juga membutuhkan inisiatif pribadi mahasiswa. Karena selama kuliah daring, mudah sekali kehilangan konsentrasi dan ketinggalan materi kuliah, maka mahasiswa harus mampu mandiri dan berinisiatif menambah pengetahuan sendiri, entah mencari dari sumber internet, buku referensi lain, mengontak teman atau dosen mata kuliah terkait."

Keberhasilan mengakuisisi pengetahuan dari dosen akan memudahkan mahasiswa menguasai materi pembelajaran sehingga dapat menyelesaikan proses belajar mengajar memenuhi target pembelajaran yang merupakan indikator pengukur efektivitas perkuliahan daring.

\section{Hubungan Faktor Universitas, Akuisisi Pengetahuan, dan Efektivitas Pembelajaran Daring}

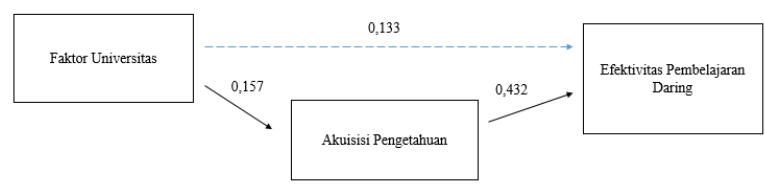

Gambar 5. Model Hubungan Faktor Universitas, Akuisisi Pengetahuan, dan Efektivitas Pembelajaran Daring

Hasil regresi terhadap hubungan variabel independen Faktor Universitas dan variabel dependen Efektivitas Pembelajaran Daring menunjukkan pengaruh variabel Faktor Universitas signifikan positif terhadap variabel Efektivitas Pembelajaran Daring. Selain itu, faktor universitas juga berpengaruh signifikan positif terhadap akuisisi pengetahuan oleh mahasiswa. Hal ini disebabkan karena proses pembelajaran daring 
tidak berhasil tanpa peran universitas sebagai fasilitator, pengajar, pemberi pengetahuan kepada mahasiswa. Faktor universitas dalam penelitian ini diukur menggunakan indikator kapabilitas pengajar memanfaatkan teknologi dan dukungan universitas $\mathrm{Hal}$ ini didukung oleh penelitian $\mathrm{Al}$ Kurdi et al (2018) yang menyatakan bahwa Kapabilitas pengajar (dosen) untuk memanfaatkan teknologi daring akan berdampak pada kesuksesan pada pembelajaran dengan metode daring, dimana pembelajaran daring membutuhkan dukungan sistem teknologi dan pengelolaan yang andal. Penelitian Iqbal et al (2020) menunjukkan bahwa universitas yang stafnya terbiasa belajar, terbuka, dan mau berkolaborasi mengembangkan pengetahuan baru akan berdampak positif pada peningkatan kepuasan mahasiswa, pengembangan kurikulum, dan kemajuan universitas. Selain itu, universitas yang mendukung proses pembelajaran daring dan telah memanfaatkan platform daring untuk mendukung proses perkuliahan konvensional, akan lebih mudah untuk melaksanakan pembelajaran daring dibanding universitas yang belum pernah melakukan sebelumnya (Jain \& Gupta, 2019). Hal ini menunjukkan peran positif faktor universitas terhadap akuisisi pengetahuan dan efektivitas pembelajaran daring.

Berdasarkan hasil analisis jalur, hubungan variabel faktor universitas terhadap efektivitas pembelajaran daring secara langsung $(\beta=-0,133)$ lebih besar daripada pengaruh variabel faktor universitas terhadap efektivitas pembelajaran daring yang dimediasi variabel Akuisisi Pengetahuan $(\beta=0,068)$. Hal ini menunjukkan pengaruh variabel Faktor Universitas terhadap Efektivitas Pembelajaran Daring tidak dimediasi oleh akuisisi pengetahuan. Pengaruh Faktor Universitas yang cukup kecil dapat disebabkan ketidaksiapan universitas dan dosen untuk mengubah pembelajaran dari konvensional menjadi daring. Komposisi dosen yang merupakan generasi babyboomers dan X cukup banyak dimana generasi tersebut memiliki kemampuan literasi teknologi yang lebih rendah dibandingkan dosen yang merupakan generasi milenial yang sudah terbiasa bersentuhan dengan perkembangan teknologi. Hal ini didukung juga oleh hasil triangulasi

"Pemanfaatan teknologi daring tentunya perlu diimbangi dengan kemampuan/ kapabilitas untuk memanfaatkan teknologi tersebut. Rendahnya literasi digital menyebabkan kurang efektifnya pemanfaatan media daring selama perkuliahan daring dan mengganggu proses transfer knowledge dari dosen ke mahasiswa"

\section{Evaluasi Perkuliahan Daring}

Berdasarkan survei yang dilakukan untuk mengevaluasi perkuliahan daring, $57 \%$ responden menyatakan proses perkuliahan daring PSIAB sudah berjalan dengan efektif, 32,5\% responden ragu ragu, dan $10,5 \%$ responden menyatakan perkuliahan daring belum berjalan dengan efektif. Jika dikelompokkan berdasarkan jenis kelamin, sebanyak $57,61 \%$ pria dan $56,25 \%$ wanita dari total responden yang menyatakan perkuliahan daring PSIAB sudah berjalan efektif, menunjukkan perbedaan hasil yang tidak signifikan jika responden dikelompokkan berdasarkan jenis kelamin. Jika dikelompokkan berdasarkan tahun perkuliahan, responden yang menyatakan perkuliahan daring sudah berjalan efektif terdiri dari 59,09\% dari total mahasiswa tahun pertama, $64,58 \%$ dari total mahasiswa tahun kedua, 54,79\% dari total mahasiswa tahun ketiga, 45,65\% dari total mahasiswa tahun keempat, dan $42,86 \%$ dari total mahasiswa yang berkuliah lebih dari empat tahun. Hal ini menunjukkan bahwa secara garis besar, proses perkuliahan daring di PSIAB sudah berjalan dengan efektif. Hal ini didukung dari hasil wawancara kepada mahasiswa sebagai berikut:

"Menurut saya, kuliah daring sudah berjalan efektif. Di samping penggunaan waktu yang maksimal sesuai jumlah SKS, bahan pengajaran daring dibuat lebih compact. Saya juga lebih nyaman berdiskusi dan berani bertanya kepada dosen di platform daring ketimbang di kelas kuliah luring. Selain, itu pemberian tugas yang nantinya dibahas oleh dosen turut membuat mahasiswa terpacu untuk memahami bahan perkuliahan terlebih dahulu sebelum perkuliahan dimulai. Hal ini juga tercermin dari nilai semester saya selama periode kuliah daring yang cukup memuaskan." 
Untuk verifikasi temuan tersebut, dilakukan juga wawancara kepada akademisi PSIAB, sebagai berikut:

"Dalam mengukur efektivitas perkuliahan daring, saya memanfaatkan indikator bloom taxonomy untuk mengukur tingkat pemahaman mahasiswa. Efektivitas dilihat dari kemampuan mahasiswa sudah mencapai tahap analyze (mampu menganalisis informasi, mengklasifikasikan, serta melihat hubungan sebab-akibat dari suatu topik bahasan baru). Lewat hasil ujian dan tugas proyek besar yang telah mahasiswa lakukan, dapat diukur kemampuan mahasiswa melakukan analisis dan tingkat pemahaman terhadap materi kuliah yang diajarkan. Selain itu, dengan sering meminta feedback dari mahasiswa, saya jadi mengetahui kendala dan kekurangan dari proses kuliah daring yang sudah berjalan saat ini sehingga dapat memperbaiki cara mengajar saya. Dari hasil tugas dan ujian, mahasiswa saya sudah mampu menganalisis sesuai bloom taxonomy analyze, sehingga secara garis besarkelas daring saya sudah berjalan secara efektif."

Dengan demikian, diperoleh kesimpulan bahwa perkuliahan daring sudah berjalan efektif, dilihat dari perspektif mahasiswa dan didukung hasil wawancara kepada akademisi. Hasil wawancara juga menunjukkan bahwa mahasiswa memperoleh nilai yang memuaskan selama mengikuti perkuliahan daring, sehingga mereka merasa bahwa perkuliahan daring sudah berjalan efektif. Persepsi mahasiswa tahun ketiga, keempat, dan lebih dari empat terhadap efektivitas perkuliahan daring lebih rendah daripada mahasiswa tahun pertama dan kedua, yang dapat diakibatkan oleh mahasiswa tahun ketiga dan keempat telah mengenal dan terbiasa dengan metode pengajaran luring di PSIAB Unpar, sehingga akan lebih nyaman dan menganggap perkuliahan daring tidak seefektif perkuliahan luring.

Lebih lanjut, $70,2 \%$ responden menyatakan lebih menyukai perkuliahan tatap muka secara langsung dibandingkan perkuliahan daring, hanya $7,1 \%$ responden yang menyukai perkuliahan daring dibandingkan perkuliahan tatap muka secara langsung, dan $22,7 \%$ responden ragu- ragu. Hasil tersebut menunjukkan sebagian besar proses perkuliahan daring di PSIAB sudah dijalankan dengan efektif, tetapi mahasiswa tetap lebih menyukai perkuliahan tatap muka secara langsung dibandingkan perkuliahan daring. Hal ini didukung oleh hasil wawancara kepada mahasiswa sebagai berikut.

"Pembelajaran daring memang mempunyai kelebihan dan kekurangan. Secara garis besar, saya merasa kuliah daring sudah cukup baik. Namun, jika harus memilih, saya dan teman-teman saya tetap memilih kuliah luring dibandingkan daring, karena kuliah luring memudahkan kami untuk belajar dan mengerjakan tugas bersamasama."

Jika dikelompokkan berdasarkan jenis kelamin, sebanyak $69,54 \%$ pria dan $70,83 \%$ wanita dari total responden menyatakan lebih menyukai perkuliahan tatap muka langsung, menunjukkan perbedaan yang tidak signifikan. Berdasarkan tahun perkuliahan, $84,85 \%$ dari total mahasiswa tahun pertama, $61,46 \%$ dari total mahasiswa tahun kedua, $65,75 \%$ dari total mahasiswa tahun ketiga, $71,74 \%$ dari total mahasiswa tahun keempat, dan $78,57 \%$ dari total mahasiswa yang berkuliah lebih dari empat tahun lebih menyukai perkuliahan tatap muka secara langsung. Tingginya angka mahasiswa tahun pertama yang lebih menyukai perkuliahan tatap muka disebabkan karena mahasiswa tahun pertama masih baru menyesuaikan diri dengan kebiasaan, budaya, dan metode pengajaran di universitas sekaligus belum pernah belajar tatap muka secara langsung dengan dosen sehingga pastinya akan mengalami kendala selama perkuliahan daring, dibandingkan mahasiswa yang lebih senior.

Berdasarkan hasil pembahasan sebelumnya, infrastruktur teknologi informasi, faktor individu (keyakinan dan kebiasaan mahasiswa), dan faktor universitas (kapabilitas pengajar dan sistem perkuliahan) berpengaruh signifikan terhadap akusisi pengetahuan oleh mahasiswa dan efektivitas pembelajaran daring. Nilai $R$ squared hasil regresi sebesar 0,637, mengartikan bahwa Akuisisi pengetahuan oleh mahasiswa dipengaruhi sebesar $63,7 \%$ oleh Infrastruktur Teknologi Informasi, Faktor 
Individu, Faktor Universitas sebesar 63,7\% terhadap dan sisanya dipengaruhi faktor-faktor lain yang tidak diteliti. Berdasarkan hasil wawancara kepada mahasiswa berkaitan dengan faktor yang mempengaruhi akuisisi pengetahuan selama perkuliahan daring, diperoleh beberapa temuan sebagai berikut

"Agar kami bisa mengakuisisi dan menguasai materi kuliah daring, penyampaian materi perlu dikemas lebih menarik, inovatif, dan tidak monoton, supaya kuliah daring lebih efektif. Jika dosen tidak terpaku hanya pada presentasi powerpoint, dapat membangkitkan suasana diskusi yang konstruktif akan membangkitkan minat mahasiswa untuk mau menyimak dan mencoba untuk memahami materi lebih dalam dari yang dijelaskan dosen. Pemberian contoh-contoh yang relevan membuat mahasiswa memperoleh gambaran materi kuliah yang lebih jelas dam tertarik dengan topik yang sedang dibahas. Kondisi kami yang berada di rumah dan lebih santai membuat mahasiswa cenderung terserang rasa malas, belum lagi jika kelas tersebut tidak mengharuskan on cam, maka jika materinya tidak disajikan dengan menarik dan inovatif, maka kami akan cenderung merasa bosan dan tidak memperhatikan. Pada akhirnya, kami tidak menguasai materi apapun."

Berdasarkan hasil wawancara tersebut, dapat dilihat bahwa metode pengajaran yang dipakai dosen selama perkuliahan daring turut berpengaruh terhadap keberhasilan akuisisi pengetahuan mahasiswa dan efektivitas pembelajaran daring. Cara mengajar masingmasing dosen tidak sama karena dipengaruhi oleh kebiasaan masing-masing dosen, jenis mata kuliah yang diampu, dan mahasiswa peserta kuliah. Responden menyatakan mereka lebih mudah fokus dan memahami materi kuliah daring apabila selama perkuliahan daring, dosen menggunakan desain visual, video, kata-kata yang menarik dan mudah dipahami, memberikan penjelasan to the point dan jelas, meningkatkan interaksi dan partisipasi mahasiswa, memberikan contoh dan studi kasus yang relevan dengan topik pembahasan untuk meningkatkan pendalaman materi. Keterbatasan komunikasi verbal dalam proses pembelajaran daring memberikan tantangan bagi para pengajar untuk mampu membuat solusi kreatif menciptakan lingkungan pembelajaran yang interaktif selayaknya proses pembelajaran luring sekaligus dapat menyampaikan esensi dari topik pembelajaran. Penyampaian materi dalam perkuliahan daring menggunakan perpaduan katakata, animasi video, dan gambar dengan tampilan menarik, disertai bantuan platform digital pendukung dapat meningkatkan minat mahasiswa untuk belajar daring dan mempermudah pemahaman materi pembelajaran daring. Semakin banyak interaksi (diskusi) baik secara synchronous atau asynchronous, semakin mudah proses berbagi dan akuisisi pengetahuan dalam kelas daring, sehingga menciptakan suasana perkuliahan daring yang positif dan membangun. Hal ini juga didukung hasil triangulasi kepada akademisi sebagai berikut:

"Pada praktiknya, hal terpenting dalam kuliah daring adalah kemampuan dosen mengajar sekaligus meningkatkan partisipasi mahasiswa, menghidupkan suasana perkuliahan, dan memanfaatkan berbagai platform untuk mendukung proses kuliah daring. Selama kuliah daring, saya mengkombinasikan pembelajaran sinkron dan asinkron. Untuk pertemuan sinkron, saya menggunakan zoom meeting, untuk membahas dan menjawab pertanyaan-pertanyaan yang diajukan mahasiswa. Untuk pertemuan asinkron, saya menggunakan platform digital, seperti Google Classroom dan Youtube untuk mengunggah video dan slide perkuliahan yang bisa diakses setiap waktu sebelum dan sesudah kuliah daring dimulai. Penggunaan metode tersebut dapat membuat style mengajar menjadi dinamis dan tidak monoton sehingga dapat membangkitkan minat dan motivasi mahasiswa untuk mengikuti kuliah daring. Saya juga mendengarkan masukan dari mahasiswa untuk membuat proses perkuliahan daring lebih baik dan efektif ke depannya."

Dengan demikian, dapat disimpulkan metode pengajaran dosen juga berpengaruh terhadap akuisisi pengetahuan oleh mahasiswa selama perkuliahan daring dan efektivitas pembelajaran daring. Berdasarkan hasil 
wawancara lebih lanjut, diperoleh temuan lain sebagai berikut:

"Berdasarkan pengalaman saya, lebih sulit fokus belajar secara daring di rumah dibanding belajar di kelas karena banyak anggota keluarga lain yang juga beraktivitas di rumah. Konsentrasi saya selama kuliah daring dapat terpecah oleh keramaian di rumah, sehingga saya ketinggalan materi dan tidak memahami topik pembahasan dengan maksimal. Kuliah daring yang terlalu santai juga menyebabkan kami gampang tergoda untuk mengalihkan perhatian ke hal lain yang tidak berhubungan dengan perkuliahan daring."

Berdasarkan hasil wawancara tersebut, dapat dilihat bahwa suasana perkuliahan dapat memudahkan dan atau menghambat mahasiswa dalam memahami dan mengakuisisi materi perkuliahan daring. Suasana perkuliahan meliputi suasana yang dibangun selama perkuliahan daring dan suasana di sekitar peserta kuliah daring. Perkuliahan daring memberikan kemudahan mengakses pembelajaran dari berbagai tempat, sehingga apabila peserta kuliah berada di tempat yang terlalu ramai akan cenderung sulit fokus dan mudah teralihkan saat mengikuti perkuliahan daring dibandingkan berada di tempat yang lebih sepi. Hal itu dapat membuat penyerapan materi kuliah daring jadi tidak maksimal. Suasana perkuliahan daring yang positif dan tidak menegangkan dapat membuat mahasiswa tidak canggung atau segan dalam berpendapat atau berdiskusi, menciptakan hubungan antara mahasiswa dan dosen yang konstruktif sehingga membuat mahasiswa tertarik untuk berpartisipasi selama perkuliahan daring. Dengan demikian, dapat disimpulkan suasana perkuliahan daring dapat berpengaruh terhadap akuisisi pengetahuan oleh mahasiswa selama perkuliahan daring.

Hasil wawancara juga menunjukkan bahwa durasi perkuliahan daring mempengaruhi akuisisi pengetahuan oleh mahasiswa selama perkuliahan daring, yang ditunjukkan sebagai berikut:

"Faktor yang bisa mengganggu penguasaan materi dan membuat kuliah daring menjadi tidak efektif adalah jika durasi perkuliahan daring tersebut melebihi waktu sesuai jumlah SKS yang seharusnya. Jika terlalu lama membuat mahasiswa jadi tidak fokus, cepat bosan, memberikan efek pusing dan sakit mata. Idealnya, waktu perkuliahan daring yg efektif kira-kira 1-1,5 jam karena fokus dalam perkuliahan tidak akan bertahan lama, kegiatan belajar jadi membosankan dan menatap monitor terlalu akan memberikan efek sakit mata. Bisa diberikan istirahat selama 5 menit kepada mahasiswa setelah 45 menit untuk meregangkan badan, mengistirahatkan mata sejenak, dan mengumpulkan fokus.",

Berdasarkan wawancara tersebut, dapat dilihat bahwa durasi perkuliahan daring yang terlalu lama membuat mahasiswa mengalami kelelahan fisik dan mental sehingga tidak dapat fokus mengikuti perkuliahan daring. Pada akhirnya, akan menghambat saat mengakuisisi pengetahuan baru dari dosen dan tidak efektifnya perkuliahan daring. Pembelajaran daring perlu disertai istirahat untuk mengistirahatkan fisik sekaligus mengembalikan fokus mahasiswa. Dengan demikian, durasi perkuliahan daring yang terlalu lama bisa berpengaruh buruk terhadap proses akuisisi pengetahuan oleh mahasiswa selama perkuliahan daring. Untuk meningkatkan efektivitas kuliah daring, dapat diatur materi mana saja yang disampaikan dalam kuliah sinkron (kuliah live) atau asinkron, sehingga durasi kuliah daring secara live tidak terlalu lama dan materi perkuliahan lebih compact.

\section{KESIMPULAN}

Penelitian ini bertujuan dan mengukur efektivitas perkuliahan daring jarak jauh serta faktor yang berkontribusi terhadap akuisisi pengetahuan untuk mendukung perkuliahan daring di PSIAB Unpar Bandung. Hasil penelitian dapat disimpulkan bahwa Faktor Individu dan Faktor Universitas berkontribusi positif terhadap akuisisi pengetahuan oleh mahasiswa, sedangkan Infrastruktur Teknologi Informasi berkontribusi negatif terhadap akuisisi pengetahuan oleh mahasiswa. Faktor Individu, Faktor Universitas, Infrastruktur Teknologi Informasi mendukung efektivitas pembelajaran daring. Hubungan antara Faktor Individu dan Efektivitas Pembelajaran Daring dimediasi Akuisisi Pengetahuan. Oleh 
karena itu, diperlukan dukungan ketiga faktor tersebut yang sama-sama bersinergi meningkatkan efektivitas pembelajaran daring. Selain ketiga faktor tersebut, akuisisi pengetahuan oleh mahasiswa juga dipengaruhi oleh cara pengajaran dosen, suasana perkuliahan, dan durasi perkuliahan daring.

Hasil penelitian juga menunjukkan perkuliahan daring di PSIAB Unpar Bandung sudah berjalan efektif. Untuk meningkatkan efektivitas perkuliahan daring, dapat dilakukan perbaikan sistem teknologi informasi penunjang perkuliahan daring, perbaikan desain perkuliahan daring untuk meningkatkan interaksi dan partisipasi antara mahasiswa dan dosen, serta penerapan blended learning yang mengkombinasikan pembelajaran luring dan daring.

Penelitian ini memiliki keterbatasan karena hanya menggunakan objek penelitian mahasiswa PSIAB Unpar saja. Penelitian bisa memperoleh hasil yang berbeda bila penelitian menggunakan objek penelitian mahasiswa program studi eksak atau teknik atau universitas yang berbeda. Keterbatasan lainnya adalah komposisi responden dalam penelitian ini tidak seragam karena responden banyak didominasi oleh mahasiswa tahun pertama dan kedua. Untuk penelitian selanjutnya, dapat dieksplorasi faktorfaktor lain yang dapat berpengaruh terhadap akuisisi pengetahuan selama proses pembelajaran di samping ketiga faktor yang sudah diteliti menggunakan teori yang berbeda. Selain itu, dapat digunakan objek penelitian yang berbeda yaitu program studi, universitas, atau institusi pendidikan yang berbeda untuk memperkaya hasil penelitian.

\section{DAFTAR PUSTAKA}

Adeinat, I. M., \& Abdulfatah, F. H. (2019). Organizational culture and knowledge management processes: case study in a public university. VINE Journal of Information and Knowledge Management Systems, 49(1), 35-53. https://doi.org/10.1108/VJIKMS-05-20180041

Al-Kurdi, O., El-Haddadeh, R., \& Eldabi, T.
(2018). Knowledge sharing in higher education institutions: a systematic review. Journal of Enterprise Information Management, $\quad 31(2), \quad 226-246$. https://doi.org/10.1108/JEIM-09-20170129

Alawamleh, M., Al-Twait, L. M., \& Al-Saht, G. R. (2020). The effect of online learning on communication between instructors and students during Covid-19 pandemic. Asian Education and Development Studies. https://doi.org/10.1108/AEDS-06-20200131

Arsana, I. M. A. (2020). Embracing educational disruption under pandemic. TheJakartaPost. Retrieved from https://www.thejakartapost.com/academia /2020/06/06/embracing-educationaldisruption-under-pandemic.html

Azzahra, N. F. (2020). Policy Brief $\mid$ Addressing Distance Learning Barriers in Indonesia Amid the Covid-19 Pandemic. CIPS Indonesia. Retrieved from https://www.cipsindonesia.org/post/addressing-distancelearning-barriers-inindonesia-amid-thecovid-19-pandemic

Bashir, M., \& Farooq, R. (2019). The synergetic effect of knowledge management and business model innovation on firm competence: A systematic review. International Journal of Innovation Science, $\quad 11(3), \quad 362-387$. https://doi.org/10.1108/IJIS-10-2018-0103

Bloice, L., \& Burnett, S. (2016). Barriers to knowledge sharing in third sector social care: a case study. Journal of Knowledge Management, 20(1), 125-145. https://doi.org/10.1108/JKM-12-20140495

Boateng, H., Dzandu, M. D., \& Tang, Y. (2014). An investigation into knowledge acquisition idiosyncrasies in Ghanaian universities. Vine, 44(4), 579-591. https://doi.org/10.1108/VINE-08-20130045

Carter, R. A., Rice, M., Yang, S., \& Jackson, H. A. (2020). Self-regulated learning in online 
learning environments: strategies for remote learning. Information and Learning Science, 121(5-6), 311-319. https://doi.org/10.1108/ILS-04-2020-0114 Cavaliere VIncenzo, Lombardi, S., \& Giustiniano, L. (2015). Knowledge sharing in knowledge-intensive manufacturing firms. An empirical study of its enablers. Journal of Knowledge Management, 19(6).

Charband, Y., \& Jafari Navimipour, N. (2018). Knowledge sharing mechanisms in the education: A systematic review of the state of the art literature and recommendations for future research. Kybernetes, 47(7), 1456-1490. https://doi.org/10.1108/K-062017-0227

Chu, K. W. (2016). Leading knowledge management in a secondary school. Journal of Knowledge Management, 20(5), 1104-1147. https://doi.org/10.1108/JKM10-2015-0390

Clark, V. L. P., \& Creswell, J. W. (2015). Understanding Research (Second). Pearson Education Inc.

Costa, V., \& Monteiro, S. (2016). Knowledge Processes, Absorptive Capacity and Innovation: A Mediation Analysis. Knowledge and Process Management, 23(3), 207-218.

Duarte Alonso, A., Kok, S., Sakellarios, N., \& O’Brien, S. (2019). Micro enterprises, selfefficacy and knowledge acquisition: evidence from Greece and Spain. Journal of Knowledge Management, 23(3), 419438. https://doi.org/10.1108/JKM-022018-0118

Dzulkifar, L. T. (2020). Kuliah dari rumah akibat COVID-19 banyak kendala: belajar dari keberhasilan Universitas Terbuka. The Conversation. Retrieved from https://theconversation.com/kuliah-darirumah-akibat-covid-19-banyak-kendalabelajar-dari-keberhasilan-universitasterbuka-137230

Esmaeelinezhad, O., \& Afrazeh, A. (2018). Linking personality traits and individuals' knowledge management behavior. Aslib Journal of Information Management,
$70(3)$,

234-251.

https://doi.org/10.1108/AJIM-01-2018-

0019

Fauzi, M. A., Nya-Ling, C. T., Thursamy, R., \& Ojo, A. O. (2019). Knowledge sharing: Role of academics towards research productivity in higher learning institution. VINE Journal of Information and Knowledge Management Systems, 49(1), 136-159.

https://doi.org/10.1108/VJIKMS-09-20180074

Gope, S., Elia, G., \& Passiante, G. (2018). The effect of HRM practices on knowledge management capacity: a comparative study in Indian IT industry. Journal of Knowledge Management, 22(3), 649-677. https://doi.org/10.1108/JKM-10-20170453

Holsapple, C. W., Jones, K., \& Leonard, L. N. K. (2015). Knowledge Acquisition and Its Impact on Competitiveness. Knowledge and Process Management, 22(3), 157-166.

Huang, R. T. (2015). Overcoming invisible obstacles in organizational learning: The moderating effect of employee resistance to change. Journal of Organizational Change Management, 28(3), 356-368. https://doi.org/10.1108/JOCM-07-20140130

Hutasoit, L. (2020). Hasil Survei, Mayoritas Mahasiswa Tidak Suka Kuliah Daring. IDN TImes. Retrieved from https://jogja.idntimes.com/life/education/li a-hutasoit-1/89-persen-mahasiswa-tidaksuka-kuliah-daring-karena-masalahinternet-regional-jogja\#: :text=Dalam penelitian itu sebanyak 89,lebih baik dari pada daring.

Ihsanuddin. (2020). Jokowi: Kerja dari Rumah, Belajar dari Rumah, Ibadah di Rumah Perlu Digencarkan. Kompas. Retrieved from

https://nasional.kompas.com/read/2020/03 /16/15454571/jokowi-kerja-dari-rumahbelajar-dari-rumah-ibadah-di-rumahperlu-digencarkan

Ilyas, A., \& Zaman, M. K. (2020). An evaluation 
of online students' persistence intentions. Asian Association of Open Universities Journal, 15(2), 207-222. https://doi.org/10.1108/aaouj-11-20190053

Iqbal, A., Latif, F., Marimon, F., Sahibzada, U. F., \& Hussain, S. (2019). From knowledge management to organizational performance: Modelling the mediating role of innovation and intellectual capital in higher education. Journal of Enterprise Information Management, 32(1), 36-59. https://doi.org/10.1108/JEIM-04-20180083

Jain, N., \& Gupta, V. (2019). The impact of knowledge management system on student performance: A case study of the University of Delhi. VINE Journal of Information and Knowledge Management Systems, 49(1), 115-135. https://doi.org/10.1108/VJIKMS-07-20180065

Jakarta Globe. (2020). Cities Turn to Online Learning to Prevent Covid-19 Spreading Among Students. Jakarta Globe. Retrieved from https://jakartaglobe.id/news/cities-turn-toonline-learning-to-prevent-covid19spreading-among-students/

Kaba, A., \& Ramaiah, C. K. (2020). Predicting knowledge creation through the use of knowledge acquisition tools and reading knowledge sources. VINE Journal of Information and Knowledge Management Systems, 50(3), 531-551. https://doi.org/10.1108/VJIKMS-07-20190106

Kasih, A. P. (2020). Mendikbud: Perguruan Tinggi di Semua Zona Dilarang Kuliah Tatap Muka. Kompas. Retrieved from https://www.kompas.com/edu/read/2020/0 6/16/103917571/mendikbud-perguruantinggi-di-semua-zona-dilarang-kuliahtatap-muka

Kemendikbud. (2020). Publikasi. Retrieved from Kemendikbud website:

Pddikti.kemendikbud.go.id

Krishnaswamy, J., Hossain, Z., Kavigtha, M. K., \&
Nagaletchimee, A. (2019). What matters for higher education success of private educational institutions? Senior students' perceptions in Malaysia. Journal of Applied Research in Higher Education, 11(3), 616-635. https://doi.org/10.1108/JARHE-07-20180142

Meskhi, B., Ponomareva, S., \& Ugnich, E. (2019). E-learning in higher inclusive education: needs, opportunities and limitations. International Journal of Educational Management, 33(3), 424-437. https://doi.org/10.1108/IJEM-09-20180282

Montgomerie, K., Edwards, M., \& Thorn, K. (2016). Factors influencing online learning in an organisational context. Journal of Management Development, 35(10), 13131322. https://doi.org/10.1108/JMD-052016-0067

Nugroho, W. S. (2020). Permasalahan Kompleks Pembelajaran Daring, Mulai Siswa hingga Pengajar Temui Hambatan. Tribun Jogja, p. 3. Retrieved from https://jogja.tribunnews.com/2020/07/29/p ermasalahan-kompleks-pembelajarandaring-mulai-siswa-hingga-pengajartemui-hambatan

Obeidat, B. Y., Mai-Maher, A. S., Masa'deh, R., \& Tarhini, A. (2016). The impact of knowledge management on innovation: An empirical study on Jordanian consultancy firms. Management Research Review, 39(10), 1214-1238.

Owusu Manu, D.-G., John Edwards, M., Parn, E. A., \& Antwi-Afari, M. (2017). The knowledge enablers of knowledge transfer: a study in the construction industries in Ghana. Journal of Engineering, Design and Technology, 16(2), 194-210.

Papa, A., Dezi, L., Gregori, G. L., Mueller, J., \& Miglietta, N. (2018). Improving innovation performance through knowledge acquisition: the moderating role of employee retention and human resource management practices. Journal of Knowledge 
https://doi.org/10.1108/JKM-09-20170391

Peterson, L., Scharber, C., Thuesen, A., \& Baskin, K. (2020). A rapid response to COVID-19: one district's pivot from technology integration to distance learning. Information and Learning Science, 121(56), 451-459. https://doi.org/10.1108/ILS04-2020-0131

Pretorius, R., Lombard, A., \& Khotoo, A. (2016). Adding value to education for sustainability in Africa with inquiry-based approaches in open and distance learning. International Journal of Sustainability in Higher Education, 17(2), 167-187.

Ridhoi, M. A. (2020). Masalah Berlapis Sekolah Daring yang Tak Selesai Lewat Subsidi Pulsa. Katadata. Retrieved from https://katadata.co.id/muhammadridhoi/be rita/5f50ebddd0f80/masalah-berlapissekolah-daring-yang-tak-selesai-lewatsubsidi-pulsa

Russanah, N. (2020). Dampak Sistem Pembelajaran Daring di Perguruan Tinggi Era Pandemi COVID-19. Pustaka Bergerak. Retrieved from https://pustakabergerak.id/artikel/dampaksistem-pembelajaran-daring-di-perguruantinggi-era-pandemi-covid-19

Sahibzada, U. F., Jianfeng, C., Latif, K. F., \& Sahibzada, H. F. (2020). Fueling knowledge management processes in Chinese higher education institutes (HEIs): the neglected mediating role of knowledge worker satisfaction. Journal of Enterprise Information Management. https://doi.org/10.1108/JEIM-07-20190197

Shih, W.-L., \& Tsai, C.-Y. (2016). The effects of knowledge management capabilities on perceived school effectiveness in career and technical education. Journal of Knowledge Management, 20(6).

Supermane, S., \& Mohd Tahir, L. (2018). An overview of knowledge management practice among teachers. Global Knowledge, Memory and Communication, 67(8-9), 616-631.
https://doi.org/10.1108/GKMC-08-20170065

Thani, F. N., \& Mirkamali, S. M. (2018). Factors that enable knowledge creation in higher education: a structural model. Data Technologies and Applications, 52(3), 424-444. https://doi.org/10.1108/DTA10-2016-0068

Thanki, S., \& Thakar, J. (2018). A quantitative framework for lean and green assessment of supply chain performance. International Journal of Productivity and Performance Management, 55(1), 7-25. Retrieved from http://www.emeraldinsight.com/doi/full/1 $0.1108 / 17410400610635471$

V. Nair, B., \& Munusami, C. (2019). Knowledge management practices. Journal of Research in Innovative Teaching \& Learning, 13(2), 174-190. https://doi.org/10.1108/jrit-01-2019-0008

Veer Ramjeawon, P., \& Rowley, J. (2017). Knowledge management in higher education institutions: enablers and barriers in Mauritius. Learning Organization, 24(5), 366-377. https://doi.org/10.1108/TLO-03-20170030

Veer Ramjeawon, P., \& Rowley, J. (2020). Enablers and barriers to knowledge management in universities: perspectives from South Africa and Mauritius. Aslib Journal of Information Management, 72(5), 745-764. https://doi.org/10.1108/AJIM-12-20190362

Watjatrakul, B. (2016). Online learning adoption: effects of neuroticism, openness to experience, and perceived values. Interactive Technology and Smart Education, 13(3), 229-243. https://doi.org/10.1108/ITSE-06-20160017

Watjatrakul, B. (2020). Intention to adopt online learning: The effects of perceived value and moderating roles of personality traits. International Journal of Information and Learning Technology, 37(1-2), 46-65. https://doi.org/10.1108/IJILT-03-2019- 
0040

Xiao, J., Sun-Lin, H.-Z., \& Cheng, H.-C. (2019). A framework of online-merge-offline (OMO) classroom for open education. Asian Association of Open Universities Journal, 14(2), 134-146. https://doi.org/10.1108/aaouj-08-20190033

Zaheer, M., \& Munir, S. (2020). Research supervision in distance learning: issues and challenges. Asian Association of Open Universities Journal, 15(1), 131-143. https://doi.org/10.1108/aaouj-01-20200003

Zapata Cantu, L. E., \& Mondragon, C. E. (2016). Knowledge management in Mexican NPOs: a comparative study in organizations with a local and national presence. Journal of Knowledge Management, 20(1), 69-87. https://doi.org/10.1108/JKM-12-20140494 